Producción visual

Laura Martínez. Gallería virtual

Martínez, Laura

\title{
Laura Martínez
}

martinezlau@gmail.com

Bachillerato de Bellas Artes, Universidad Nacional de

La Plata, Argentina

Plurentes. Artes y Letras

Universidad Nacional de La Plata, Argentina

ISSN: 1853-6212

Periodicidad: Anual

núm. 12, e041, 2021

revistaplurentesunlp@gmail.com

URL: http://portal.amelica.org/ameli/

jatsRepo/186/1862378031/index.html

DOI: https://doi.org/10.24215/18536212e041

\section{(c) (1) (2)}

Esta obra está bajo una Licencia Creative Commons AtribuciónNoComercial-CompartirIgual 4.0 Internacional.

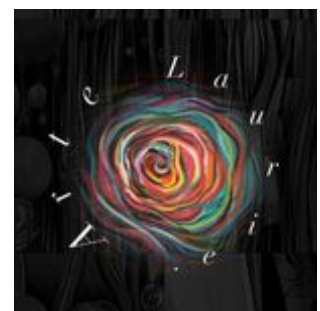

Instagram de arte @laurie.arte

Instagram personal@_martinezlauri

Facebook Laura Martínez Artista Visual 


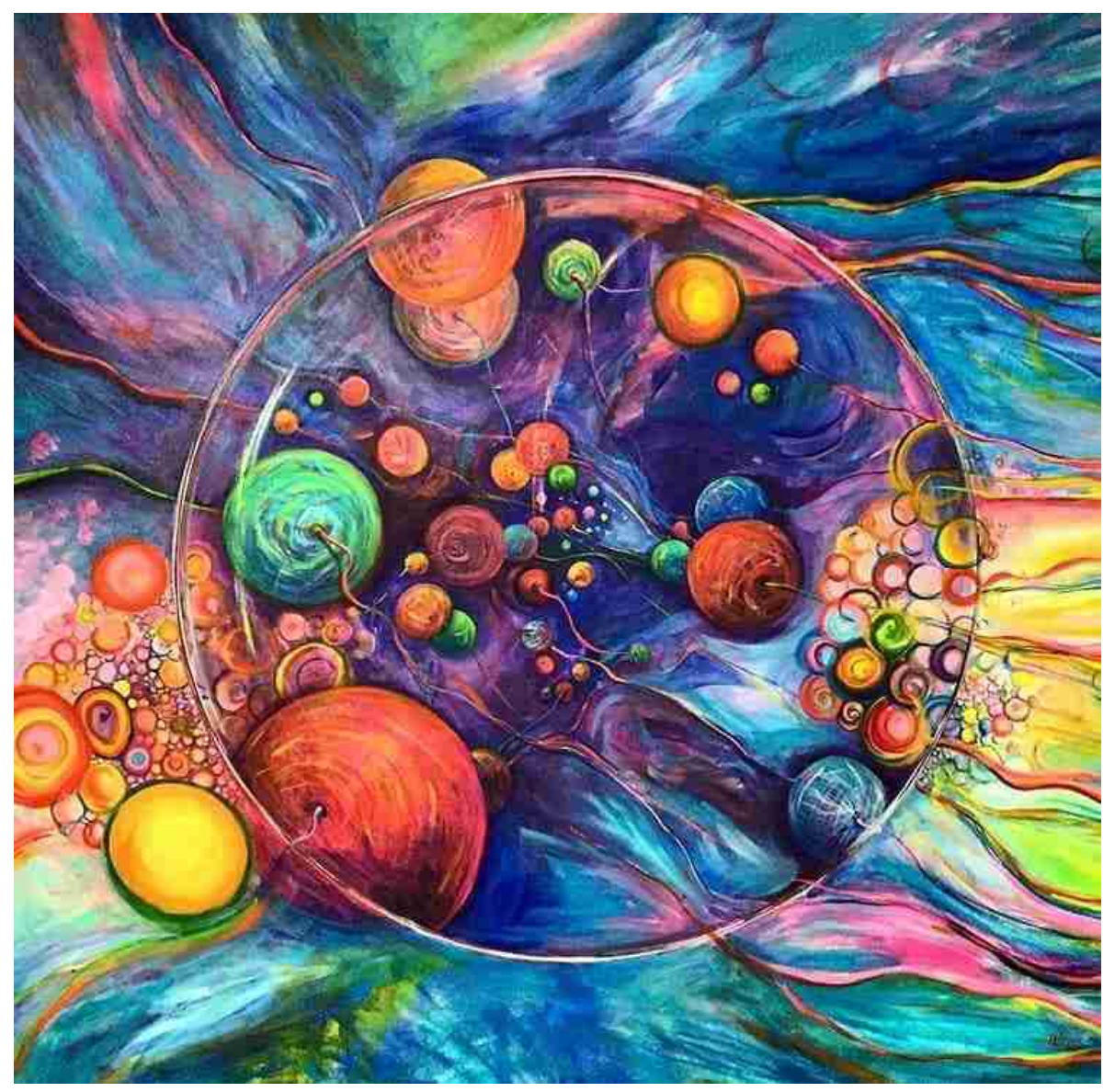

Movimiento Infinito

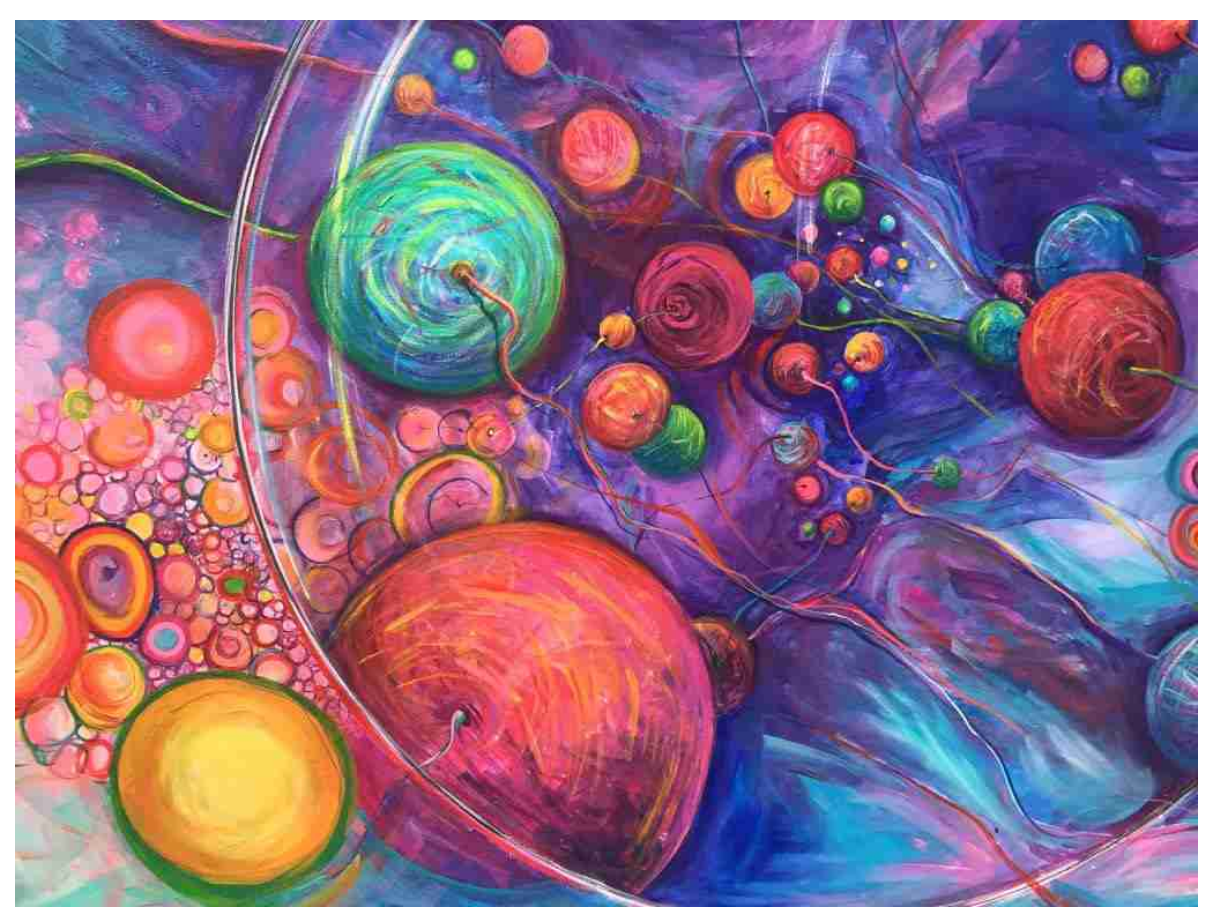

Movimiento Infinito (detalle - 1) 


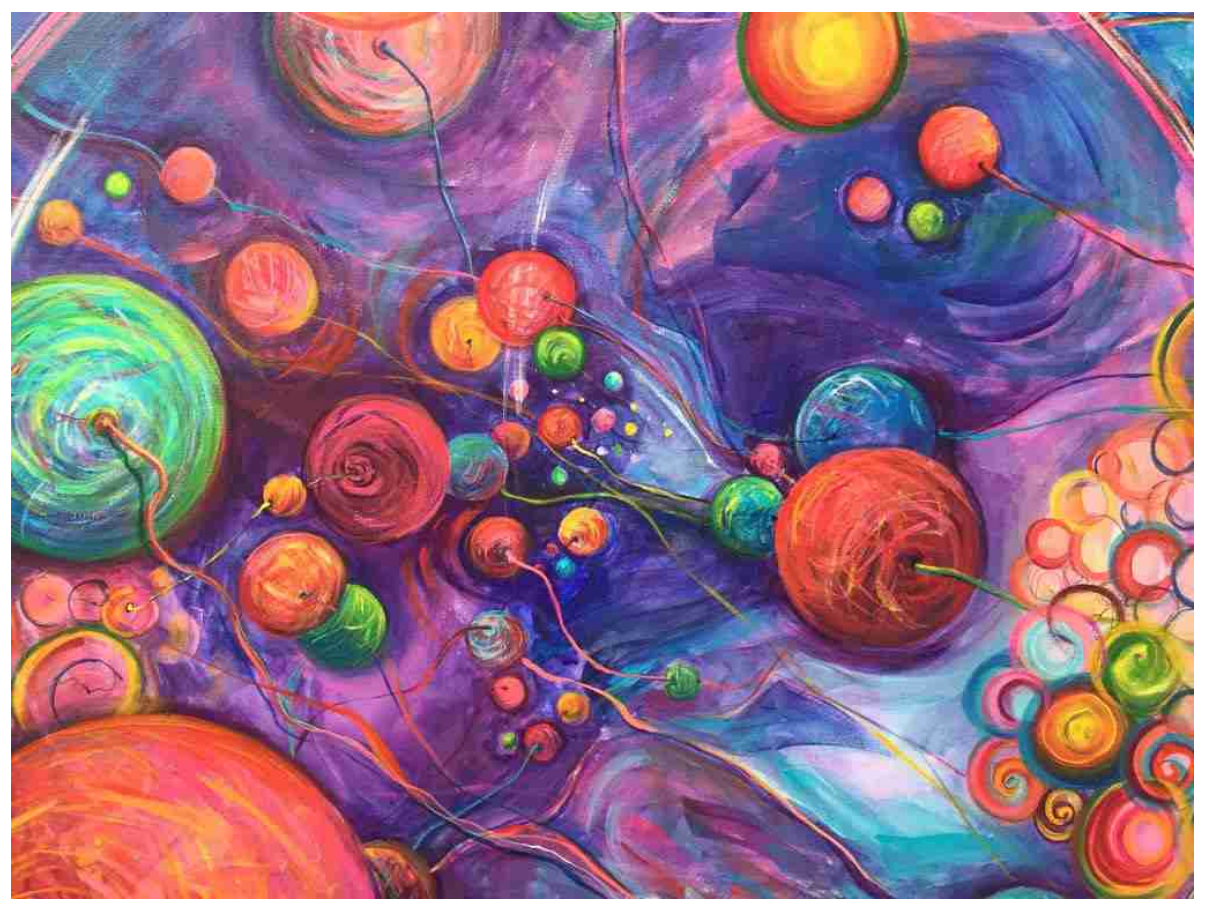

Movimiento Infinito (detalle - 2)

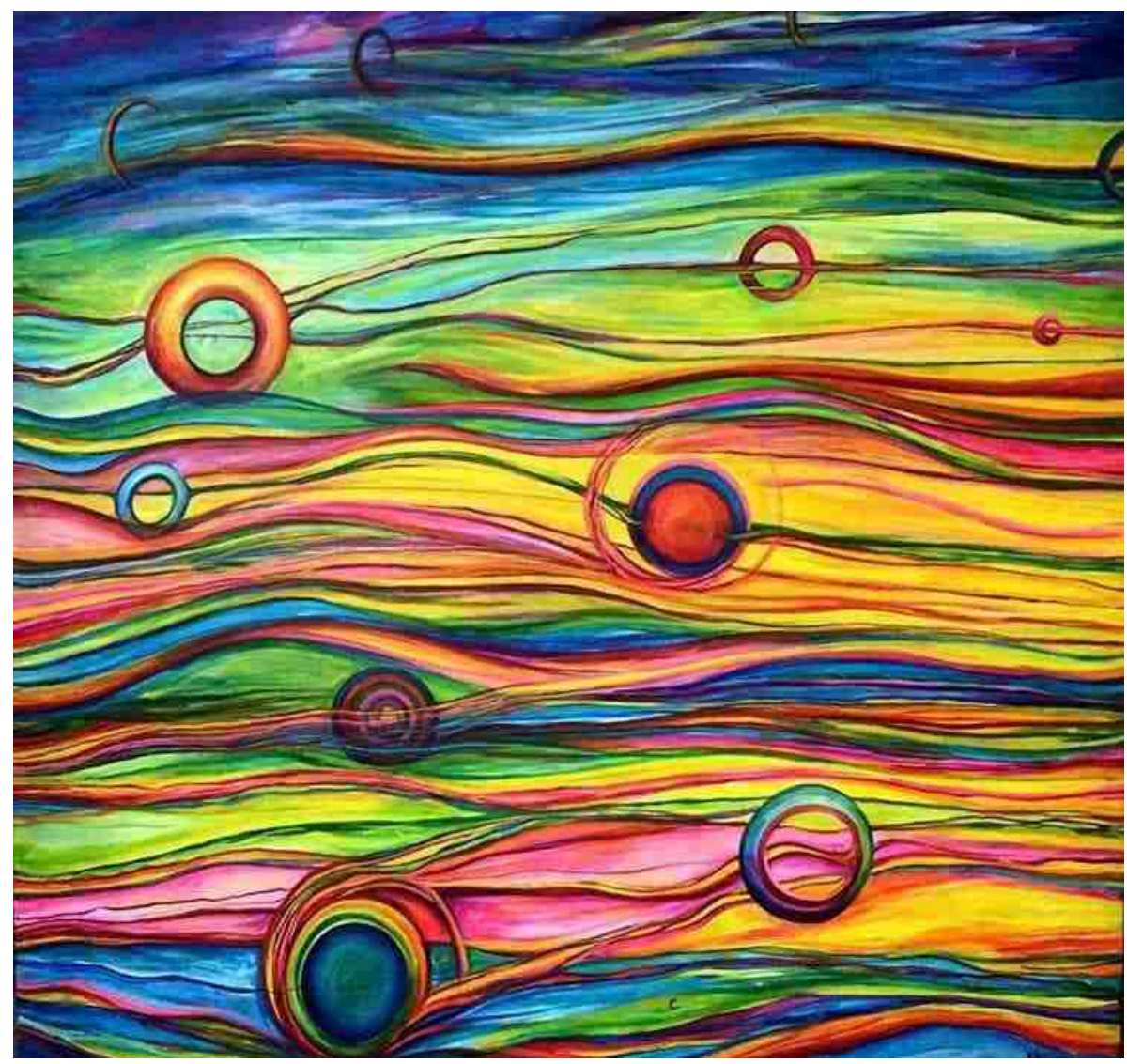

Breve Fluir 


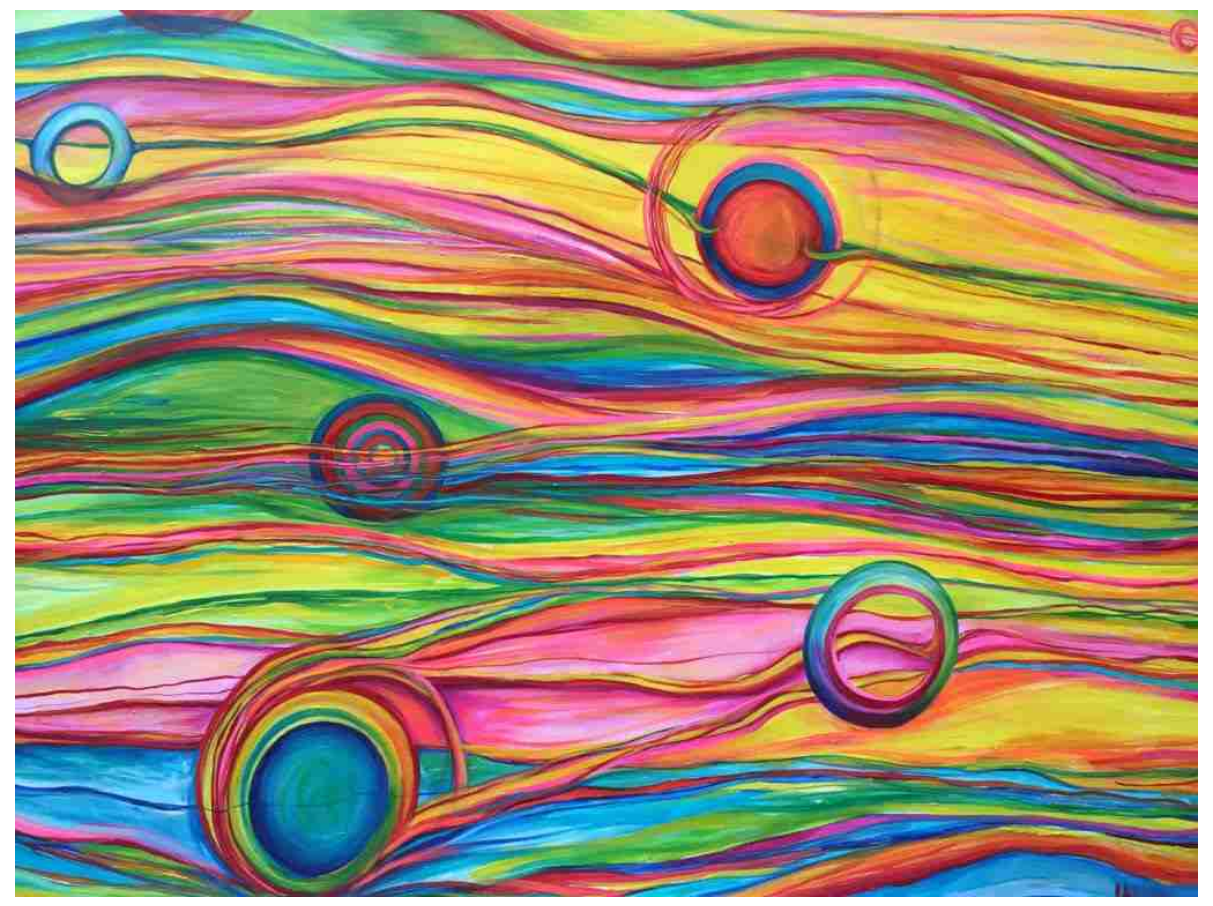

Breve Fluir (detalle - 1)

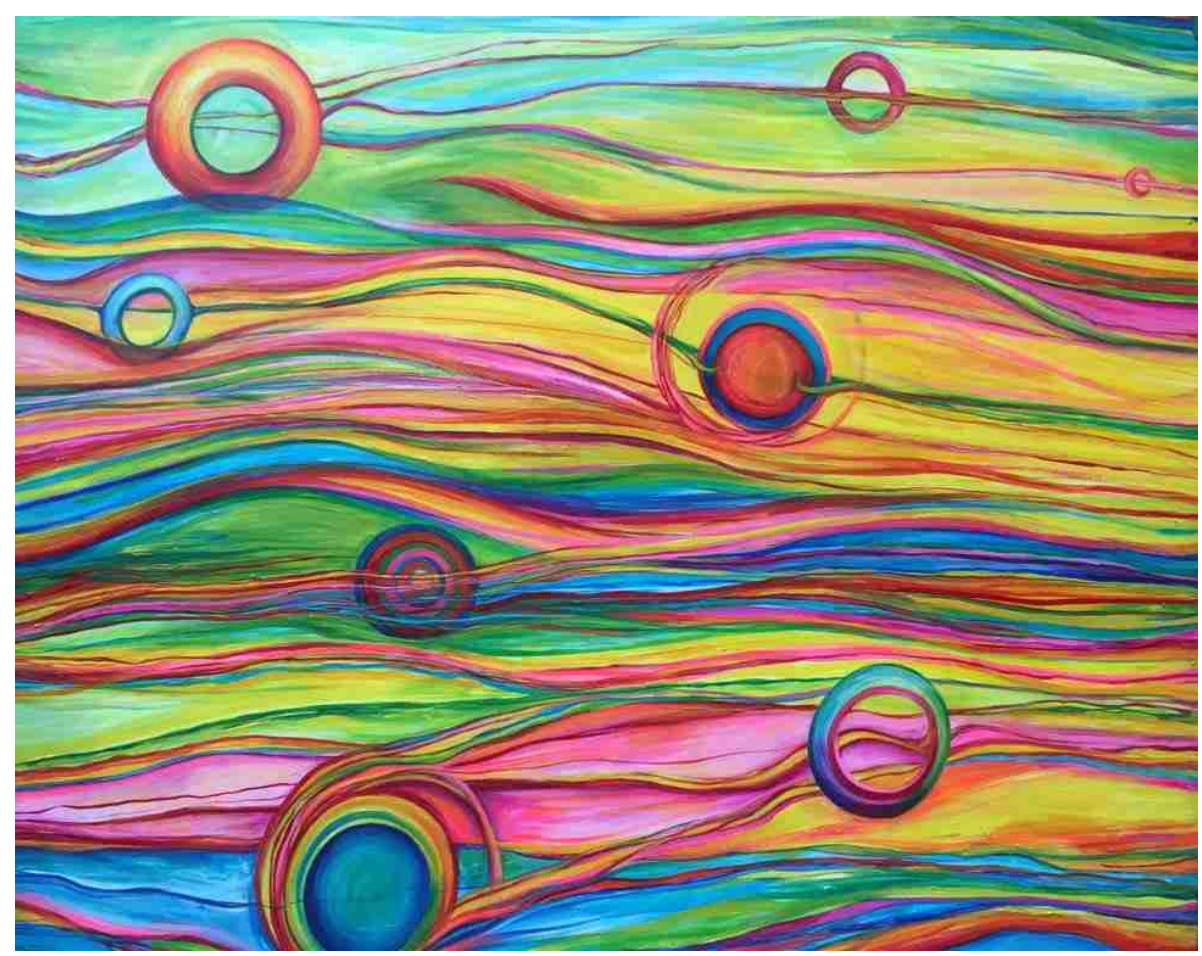

Breve Fluir (detalle - 2) 


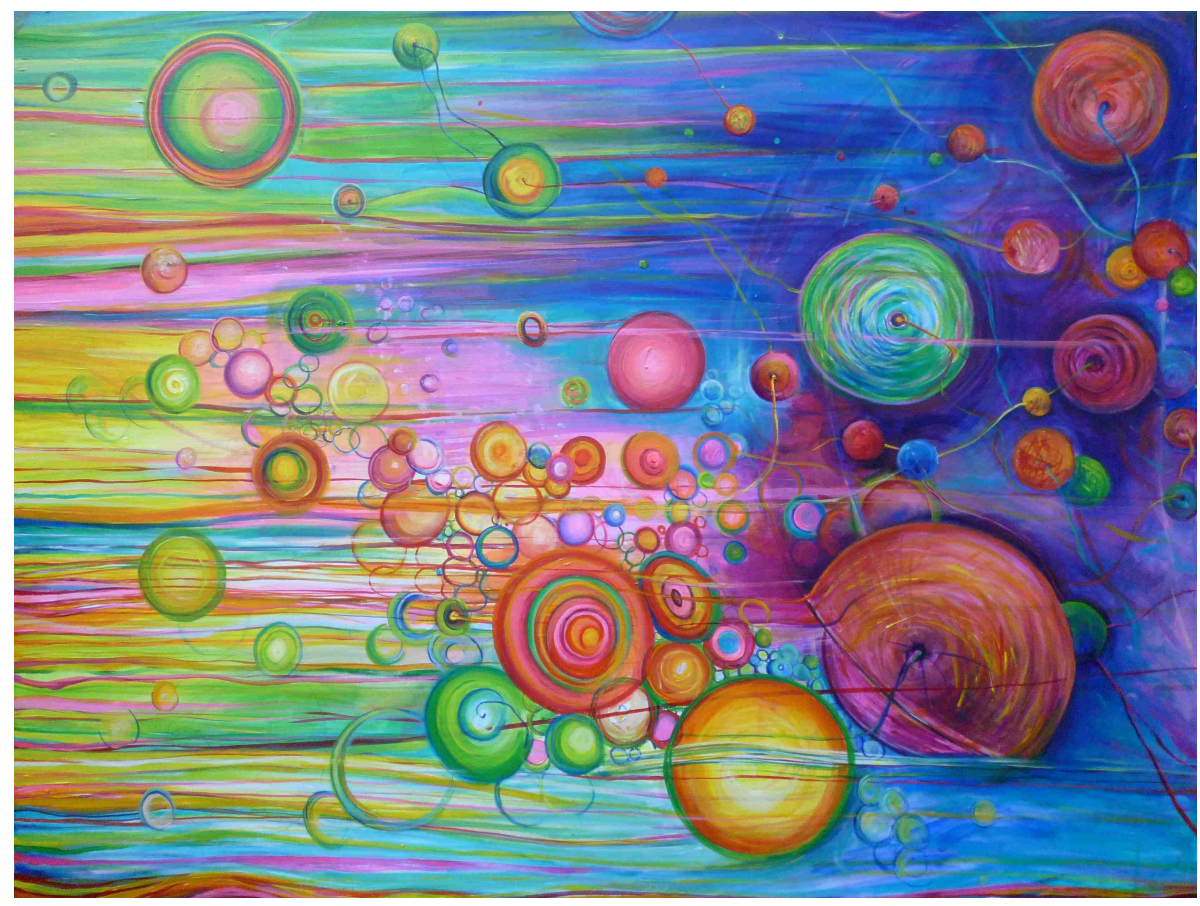

Vibrato

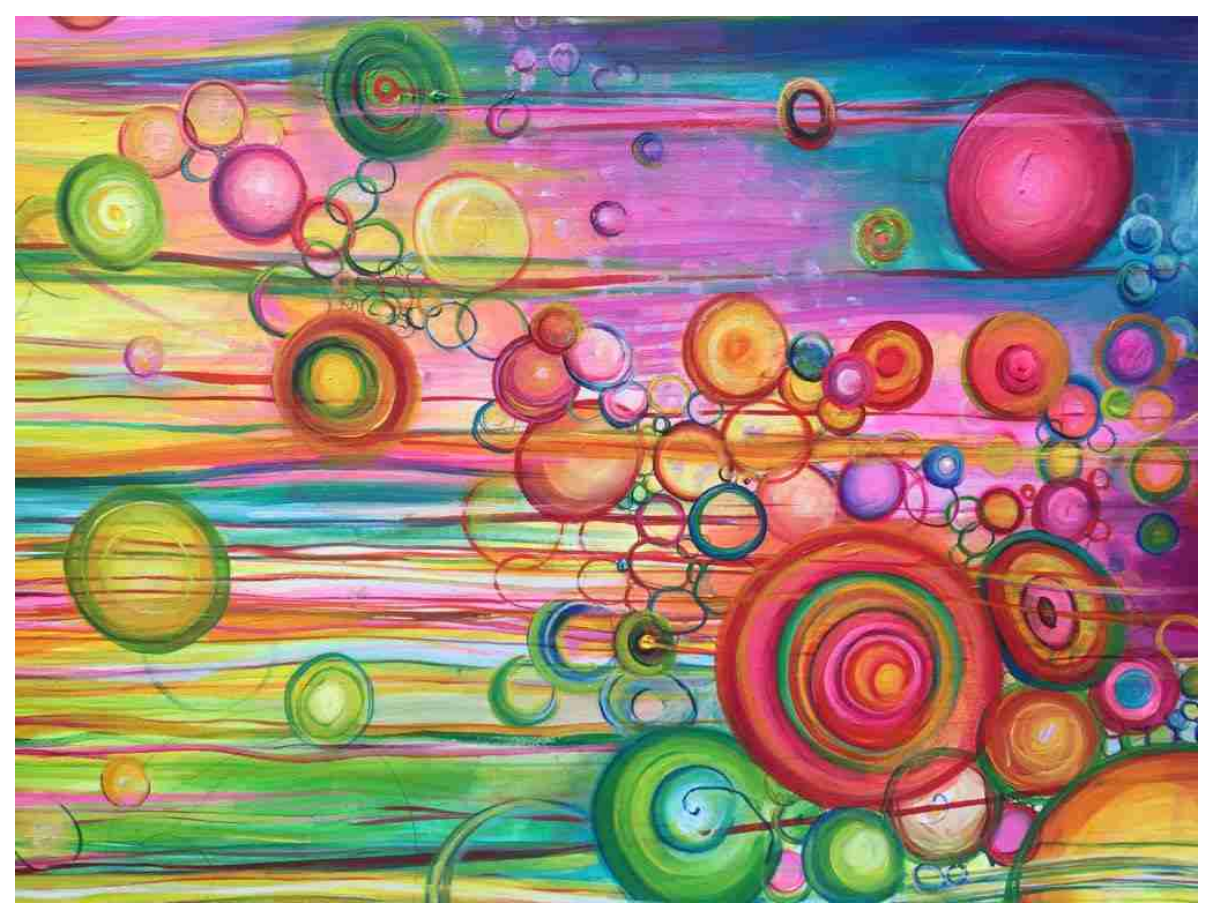

Vibrato (detalle - 1) 


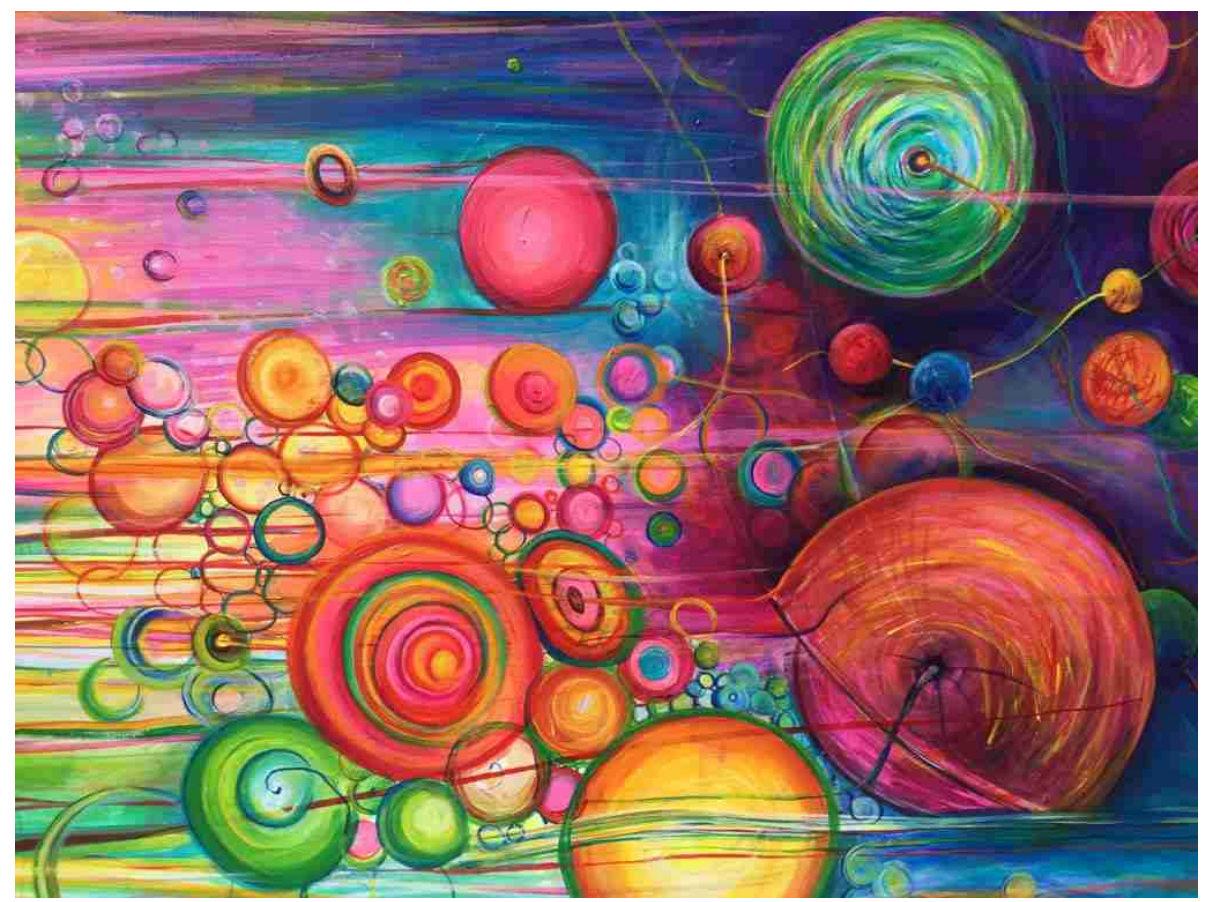

Vibrato (detalle - 2)

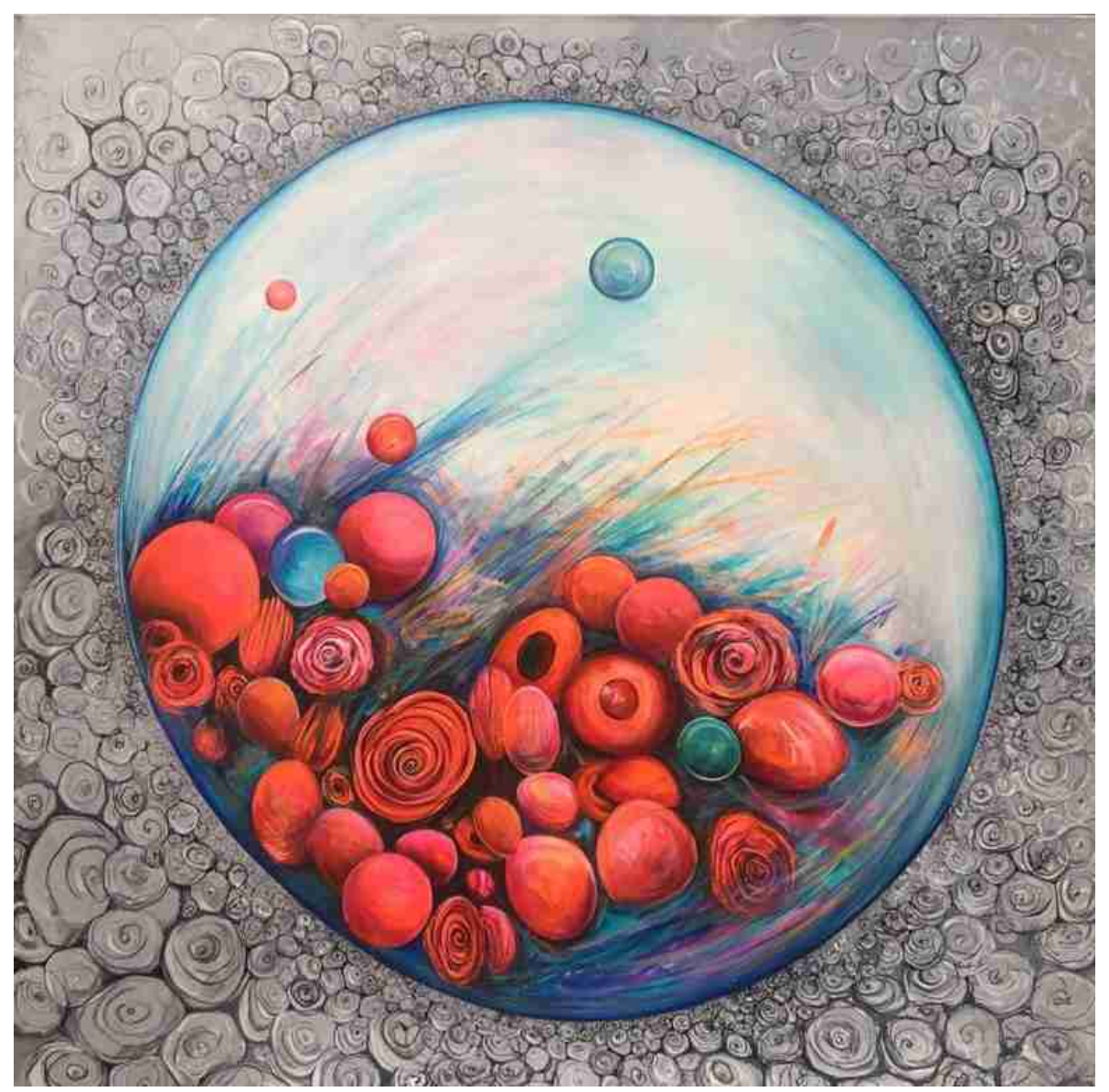

Alteridad 


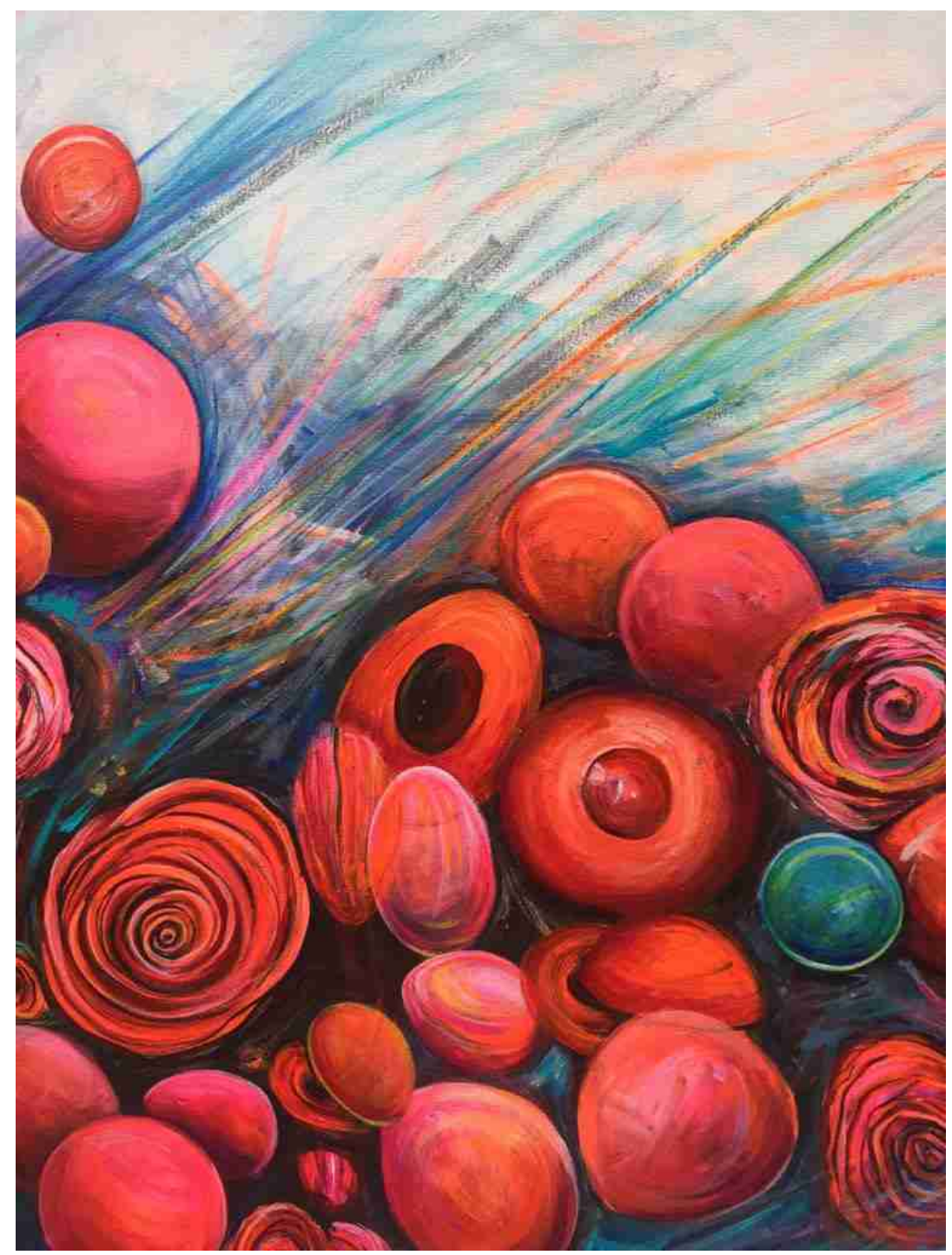

Alteridad (detalle - 1) 


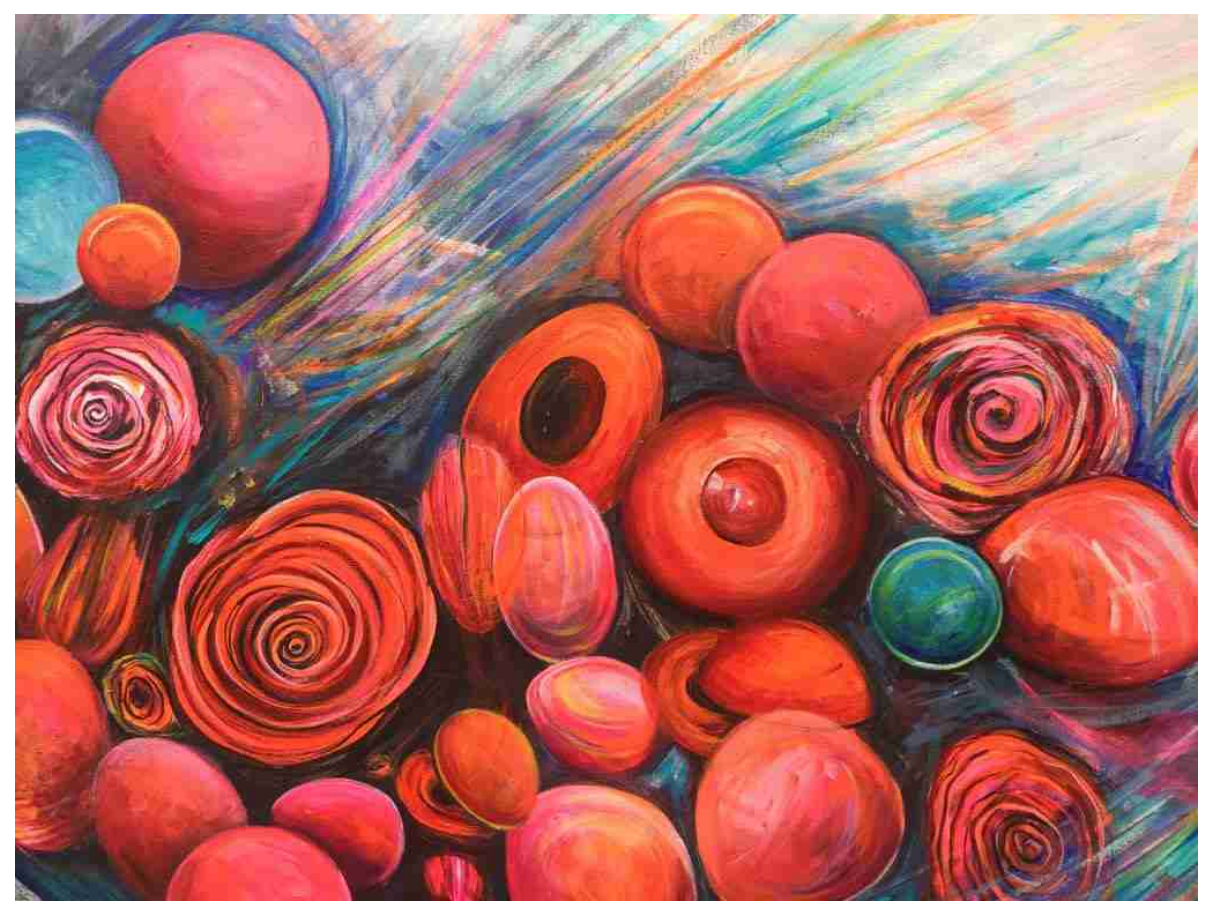

Alteridad (detalle - 2) 


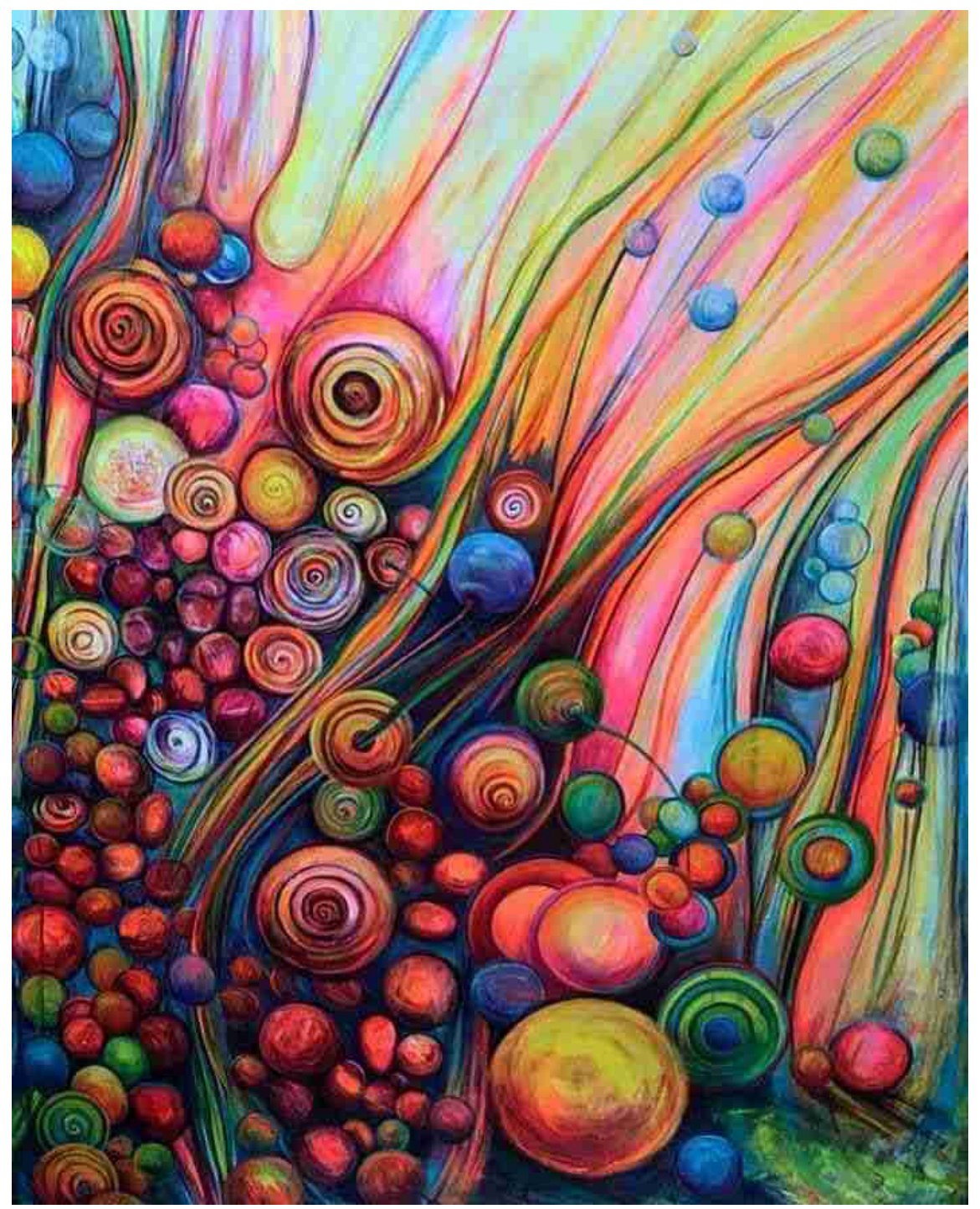

Bajo Fondo 


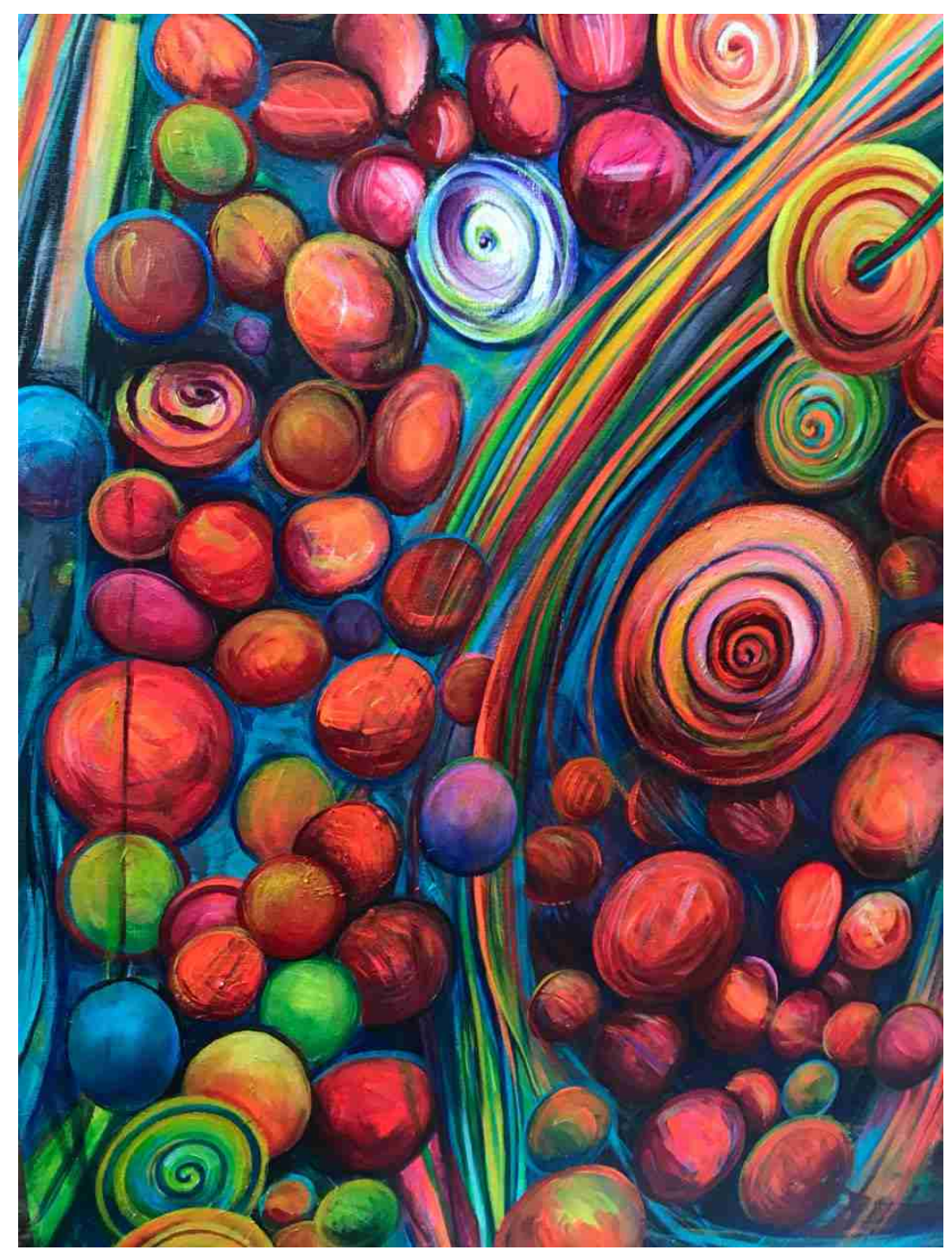

Bajo Fondo (detalle) 


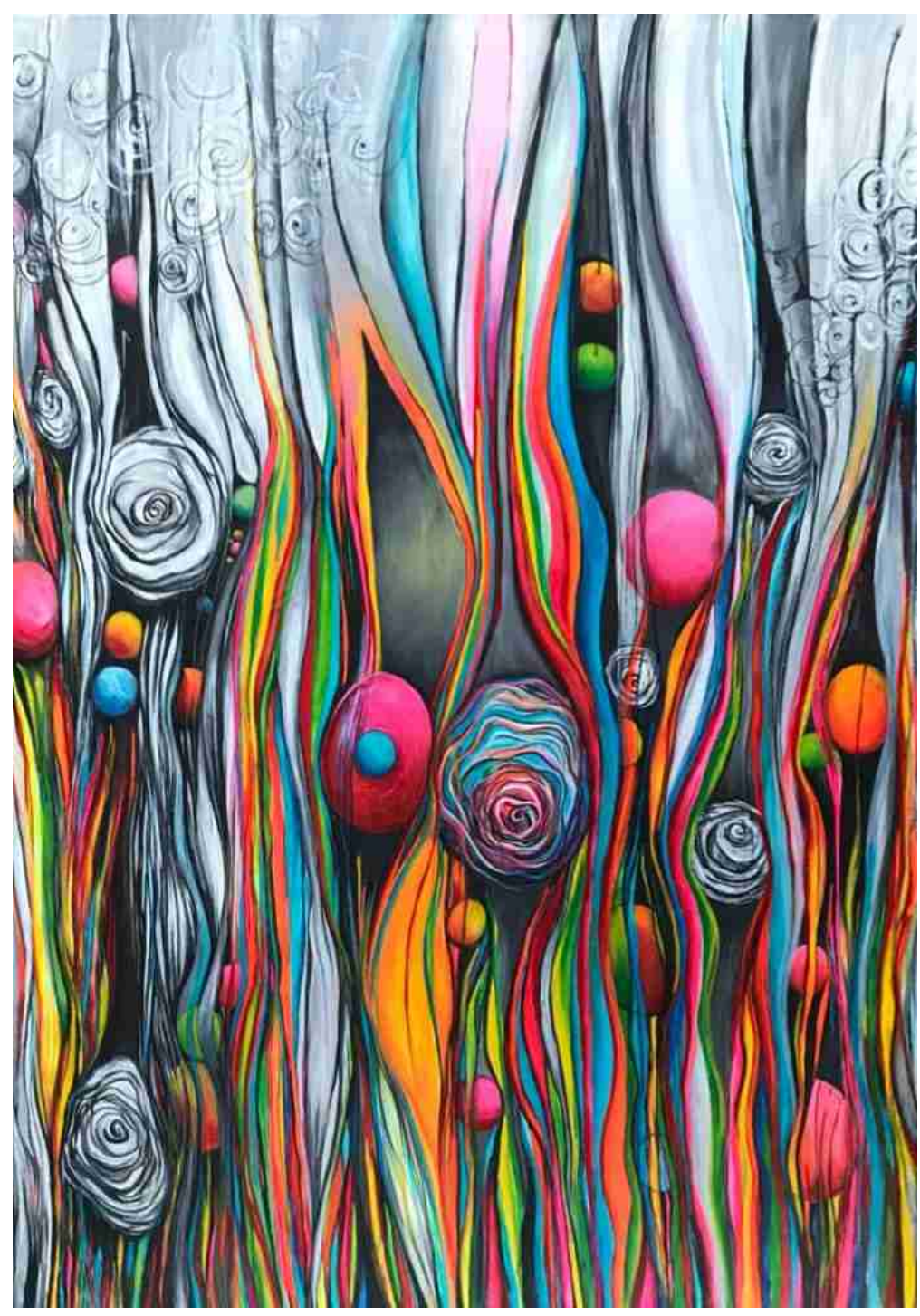

Fuerza Pulsional 


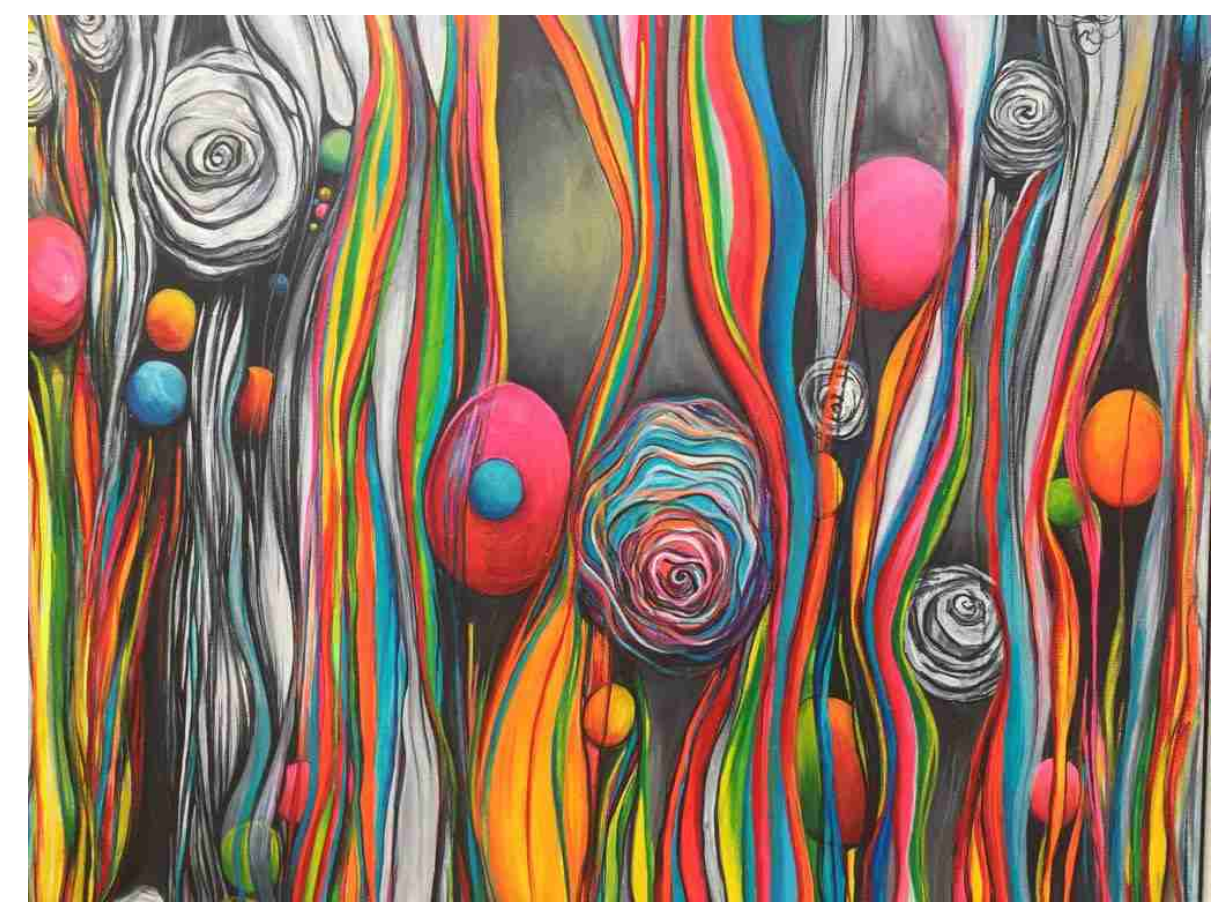

Fuerza Pulsional (detalle - 1)

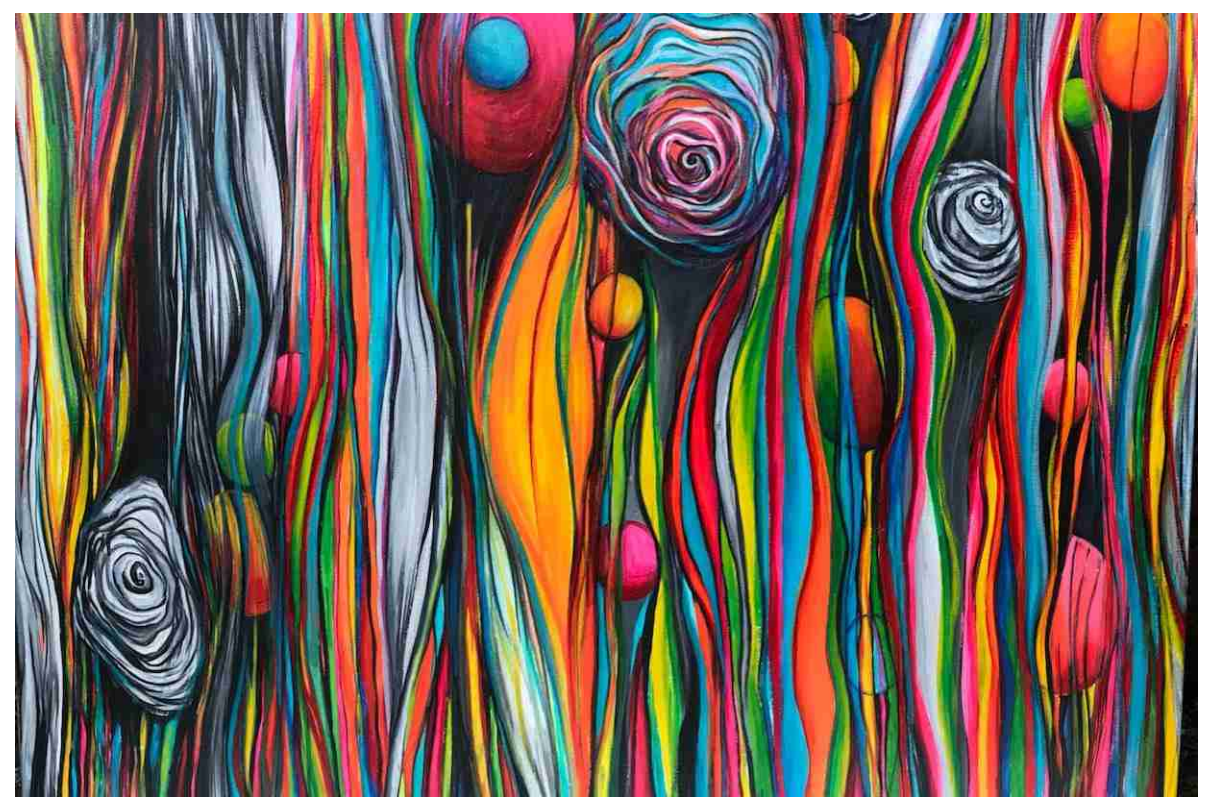

Fuerza Pulsional (detalle - 2) 


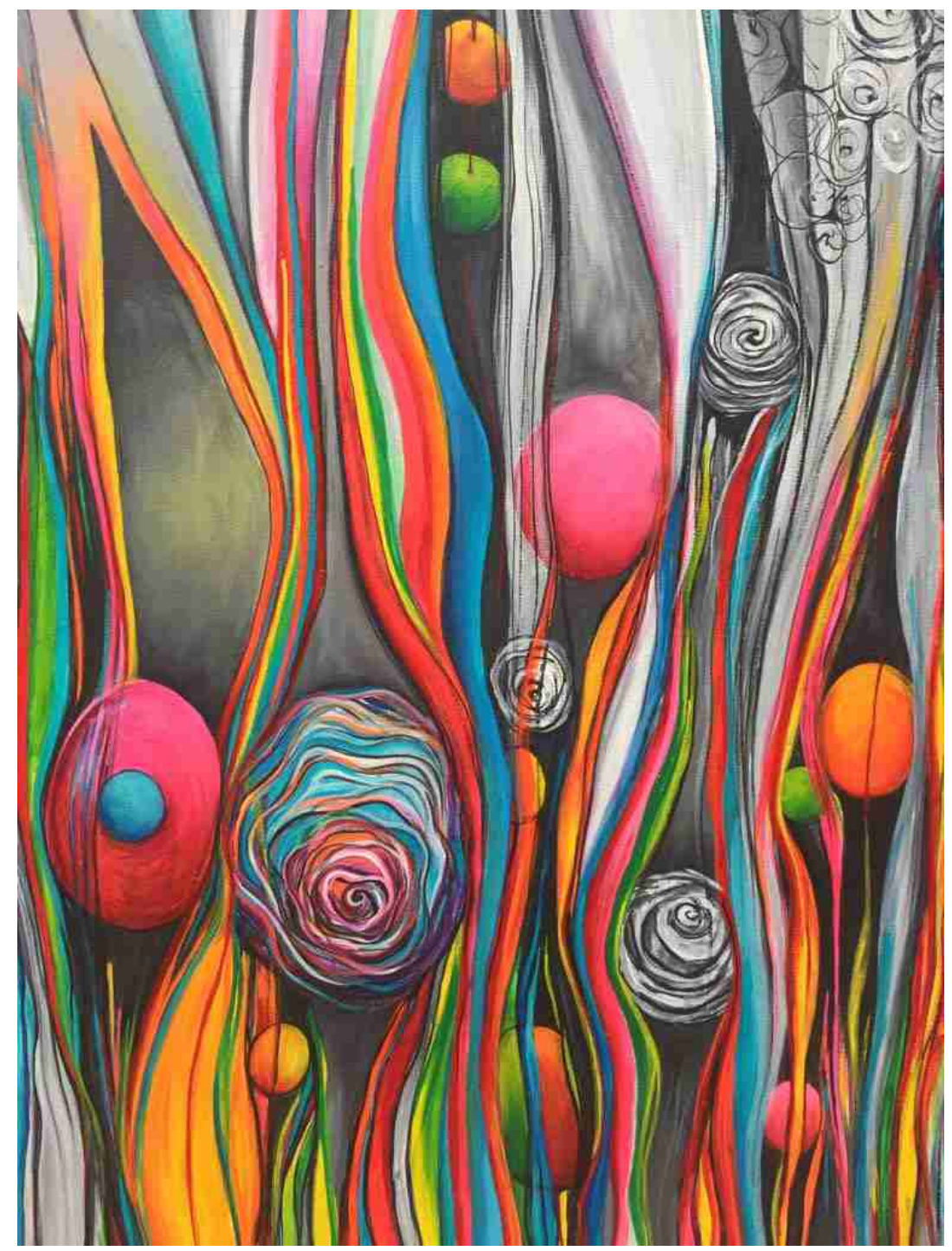

Fuerza Pulsional (detalle - 3) 


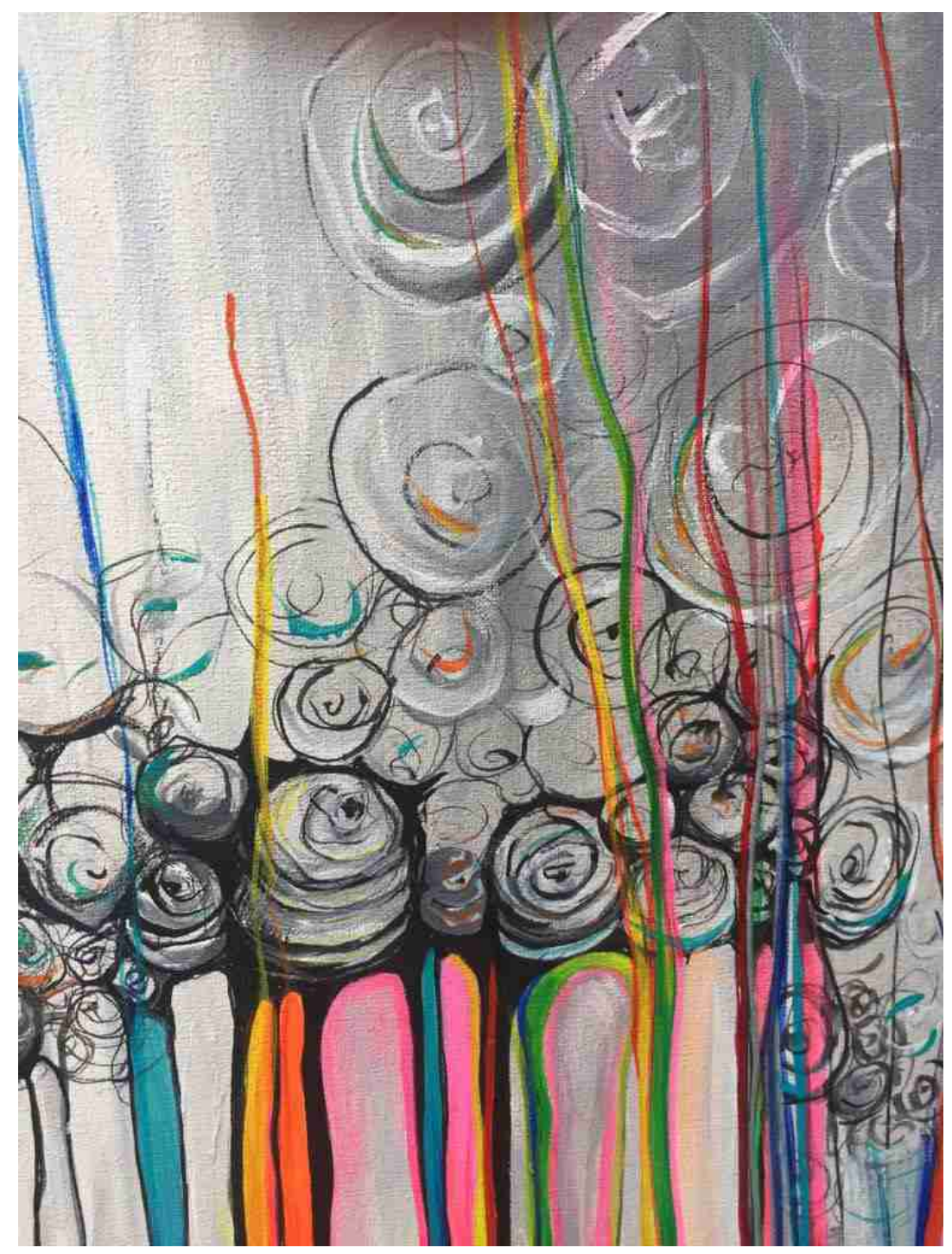

Bajo Presión (detalle - 1) 


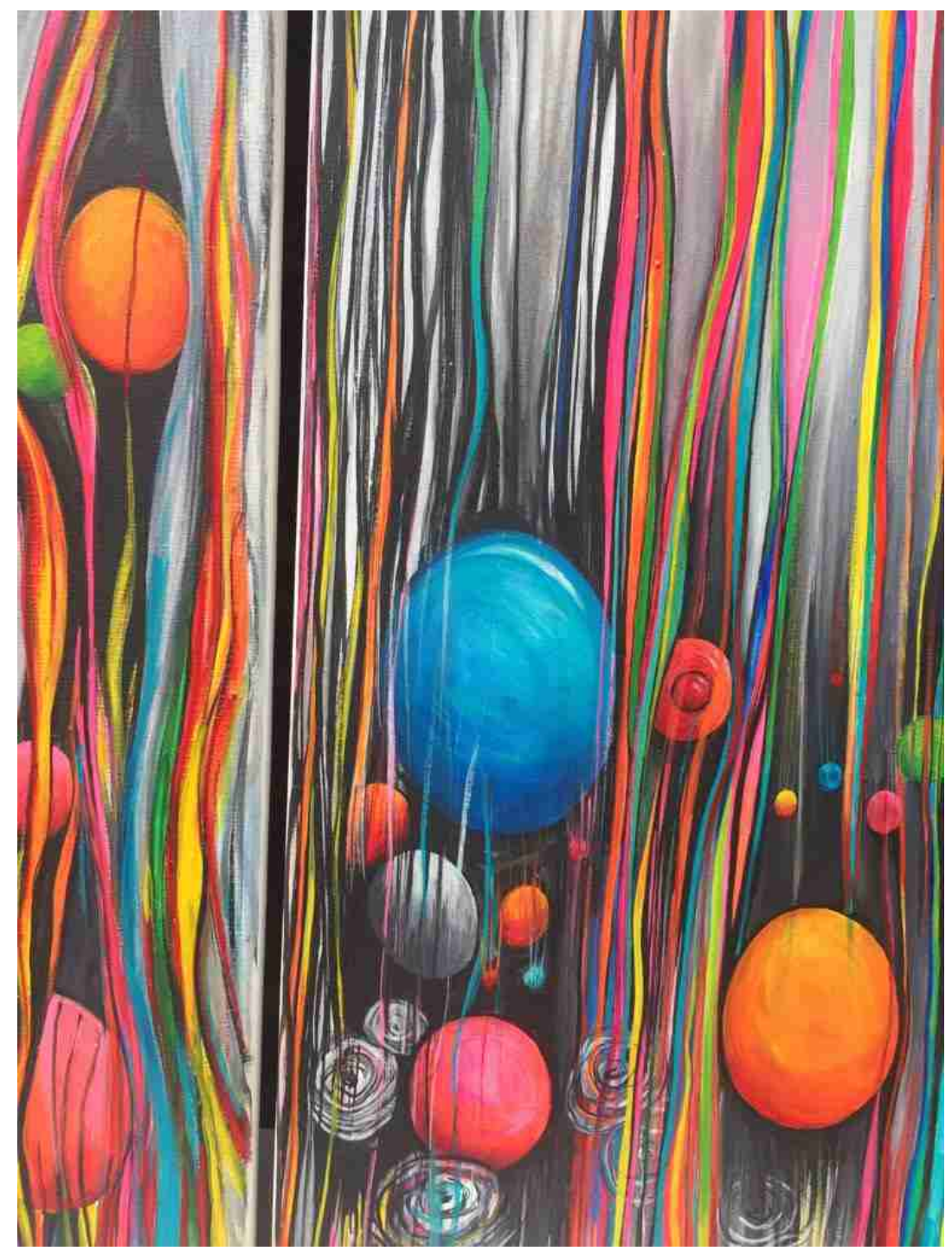

Bajo Presión (detalle - 2) 


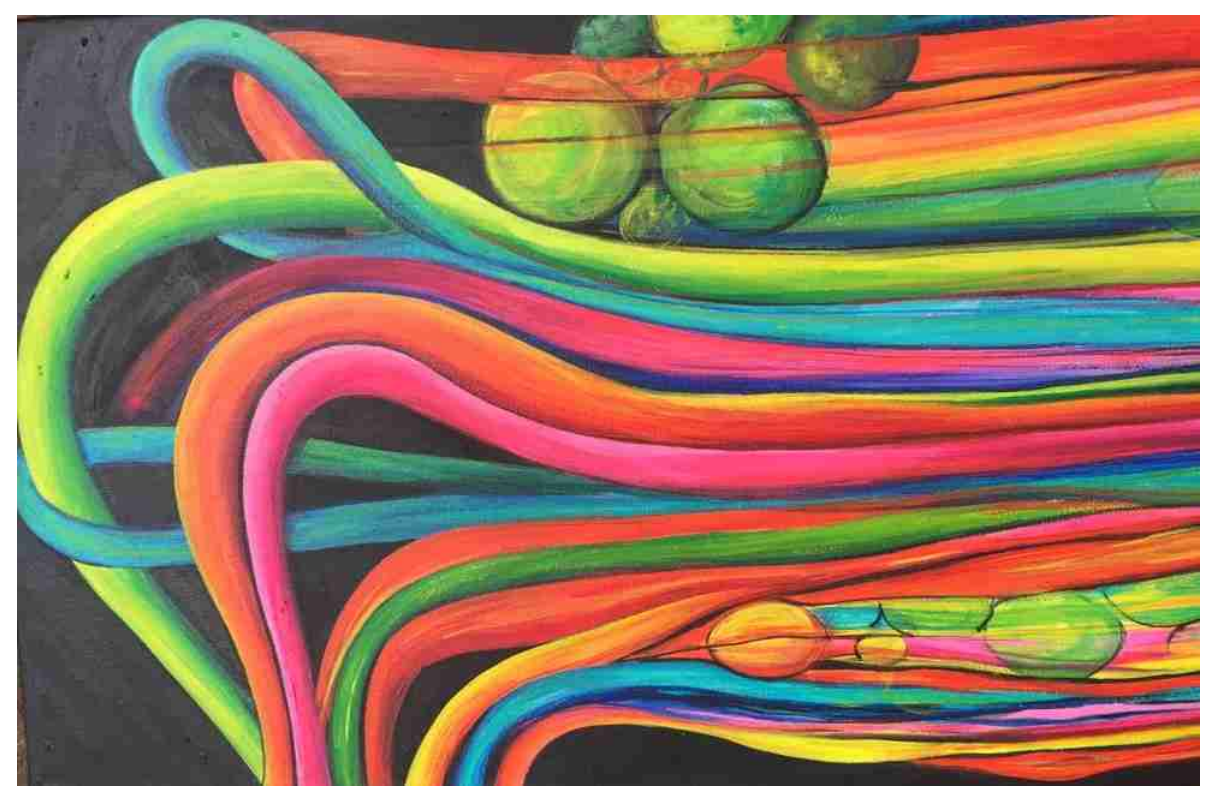

Bon Fim (detalle - 1) 


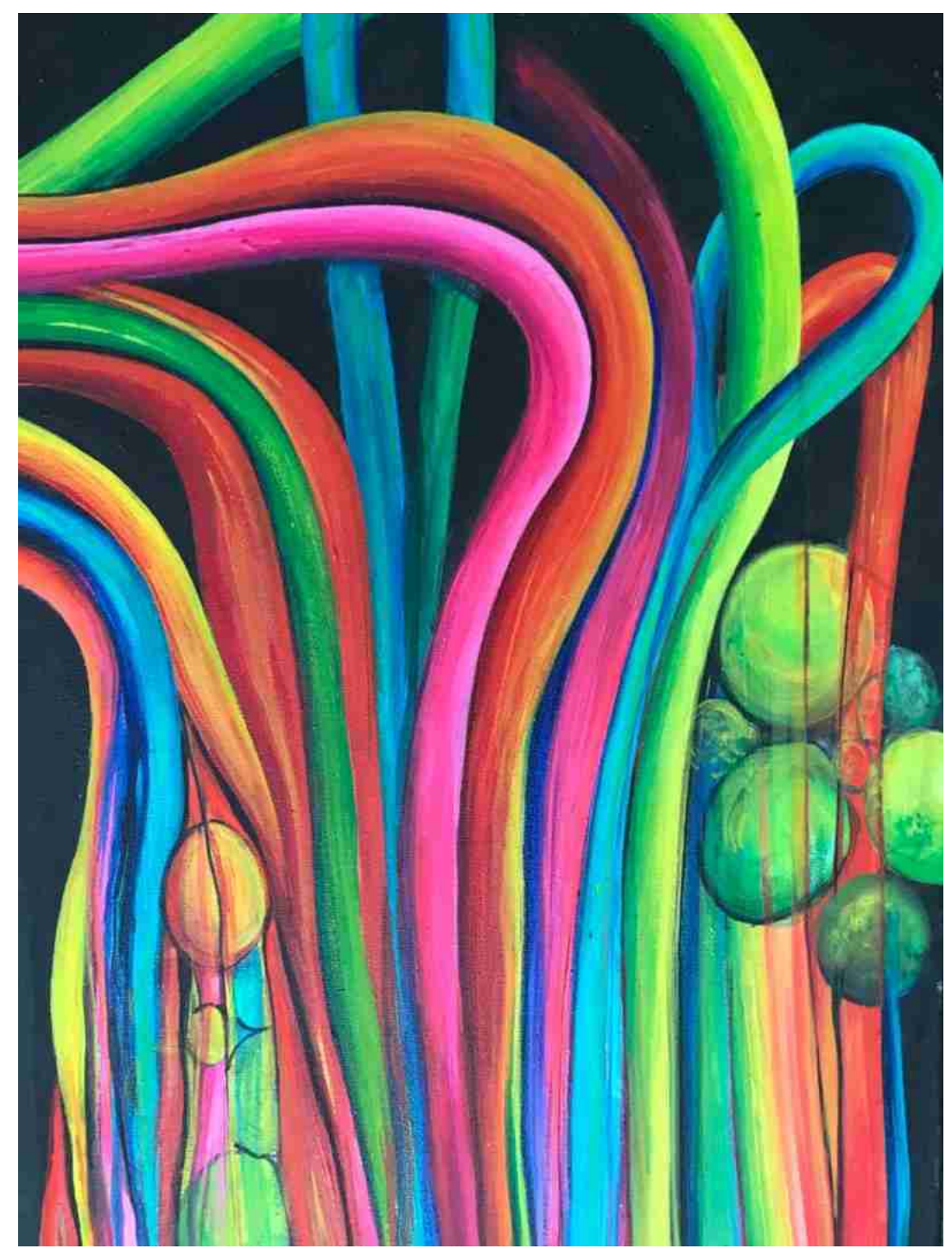

Bon Fim (detalle - 2) 
Plurentes, 2021, núm. 12, e041, Octubre-Septiembre, ISSN: 1853-6212

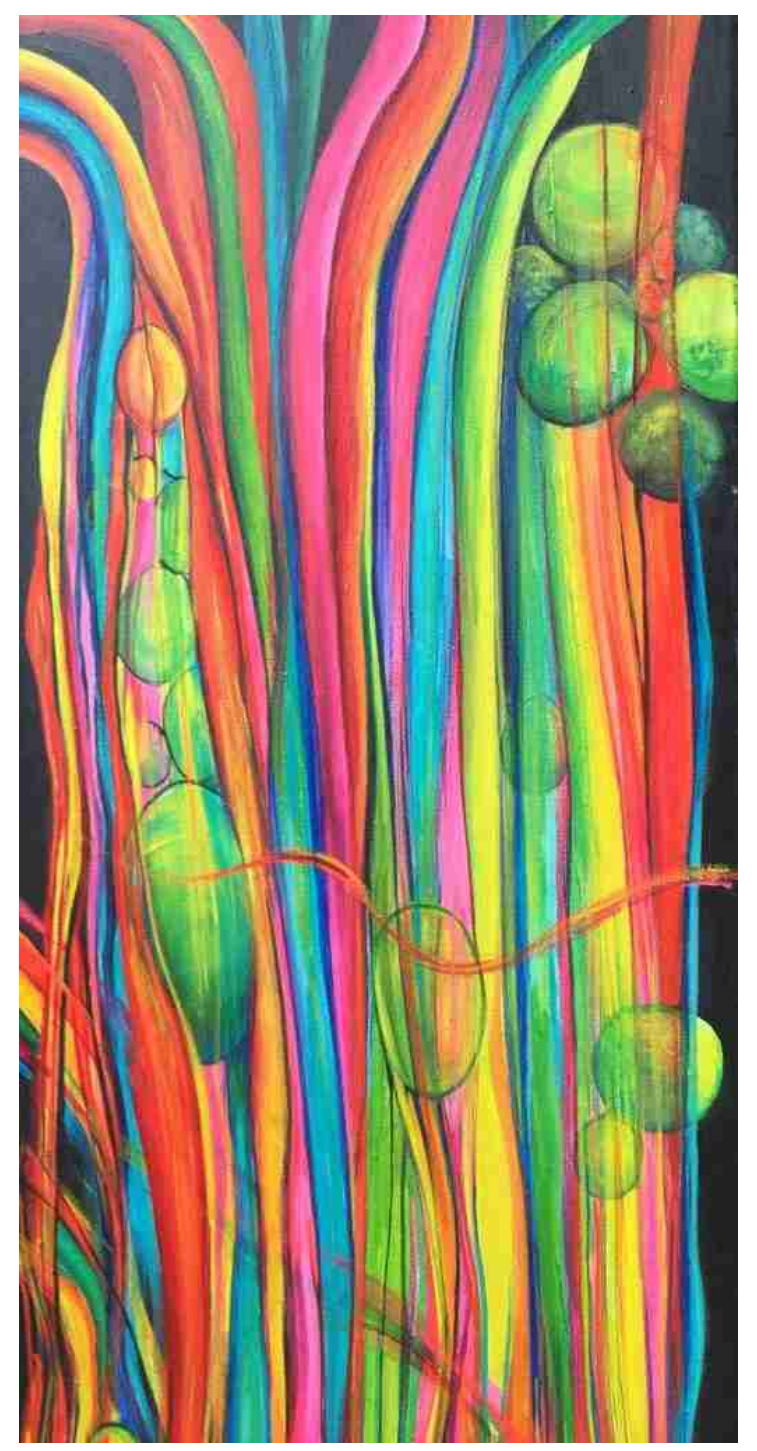

Bon Fim (detalle - 3) 


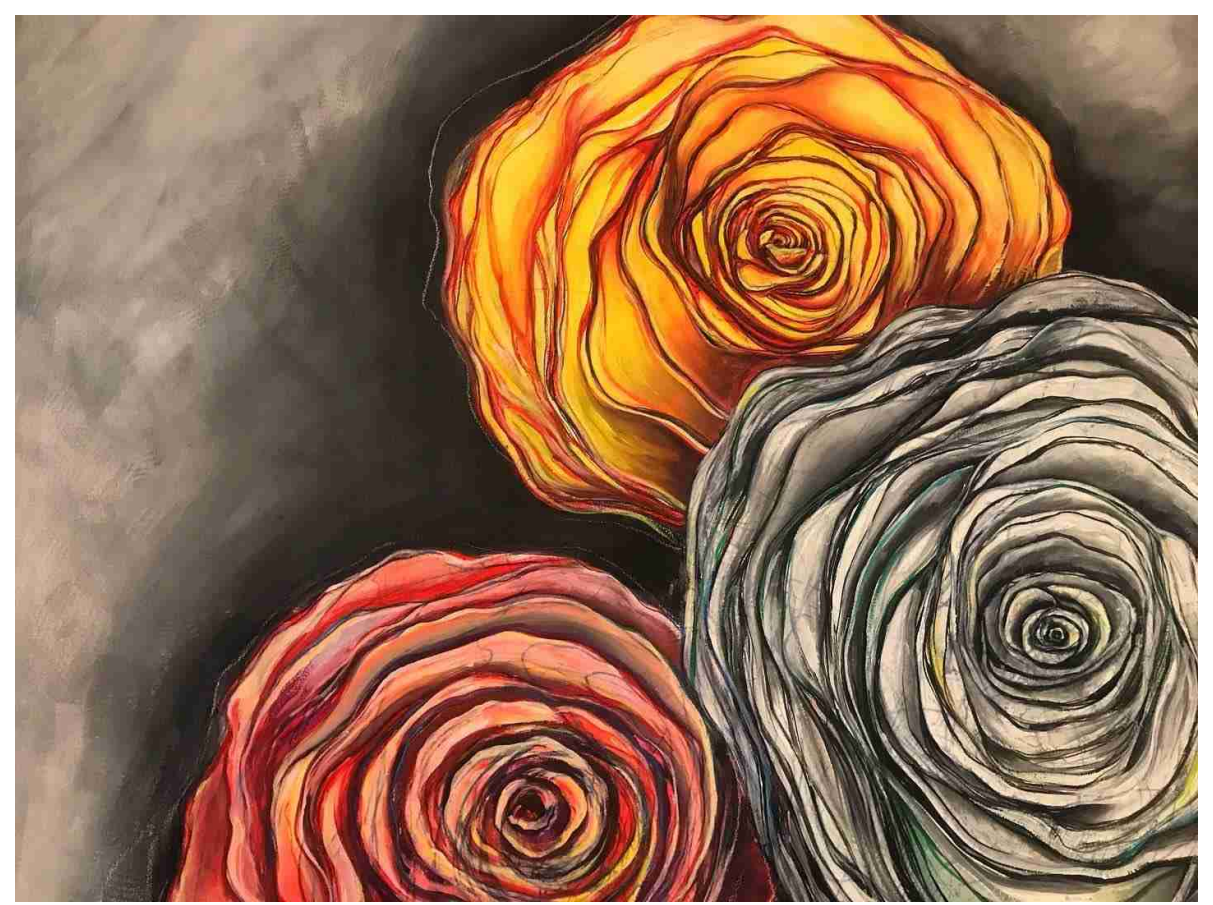

Disrupción (detalle)

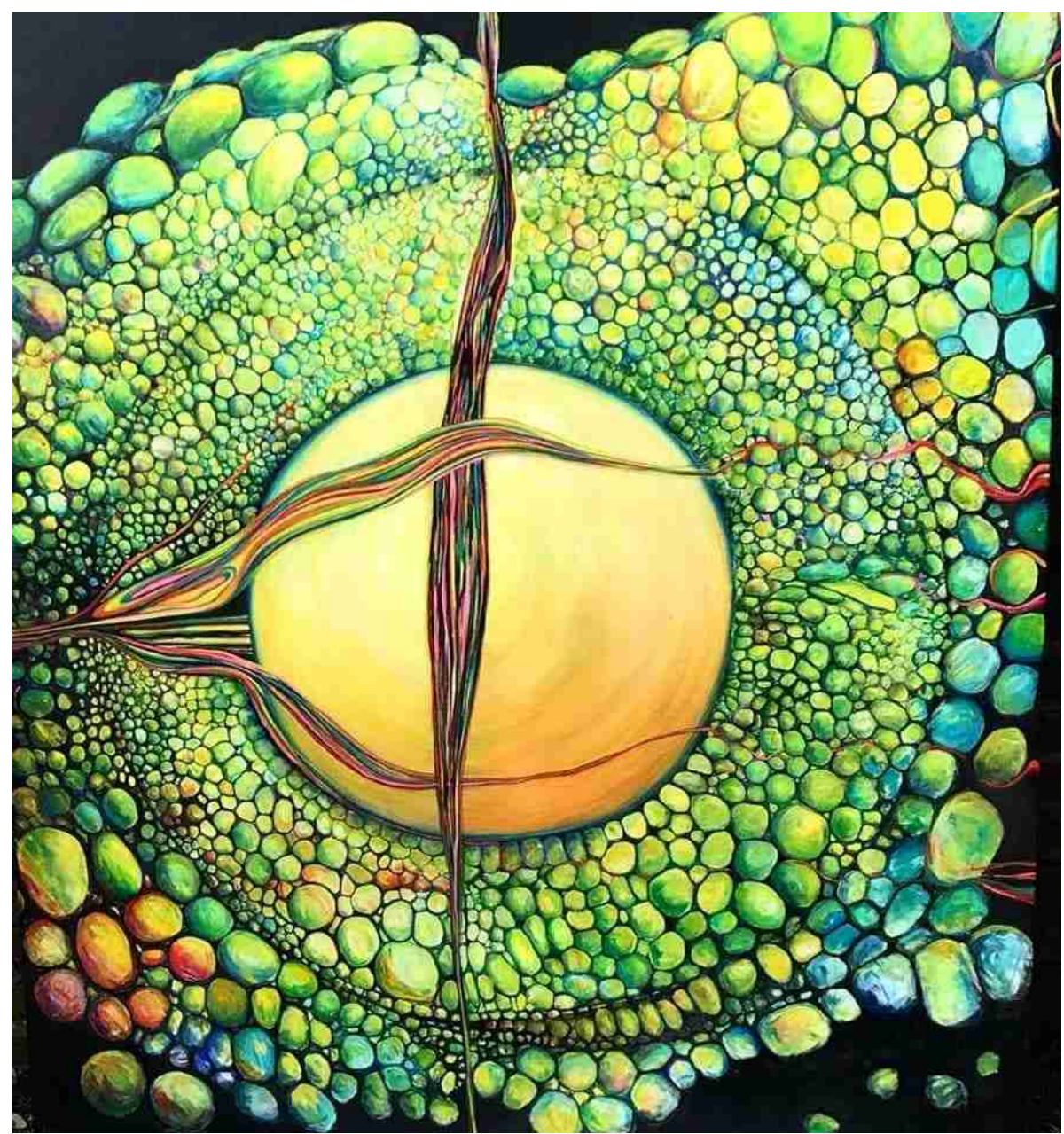

Organius 


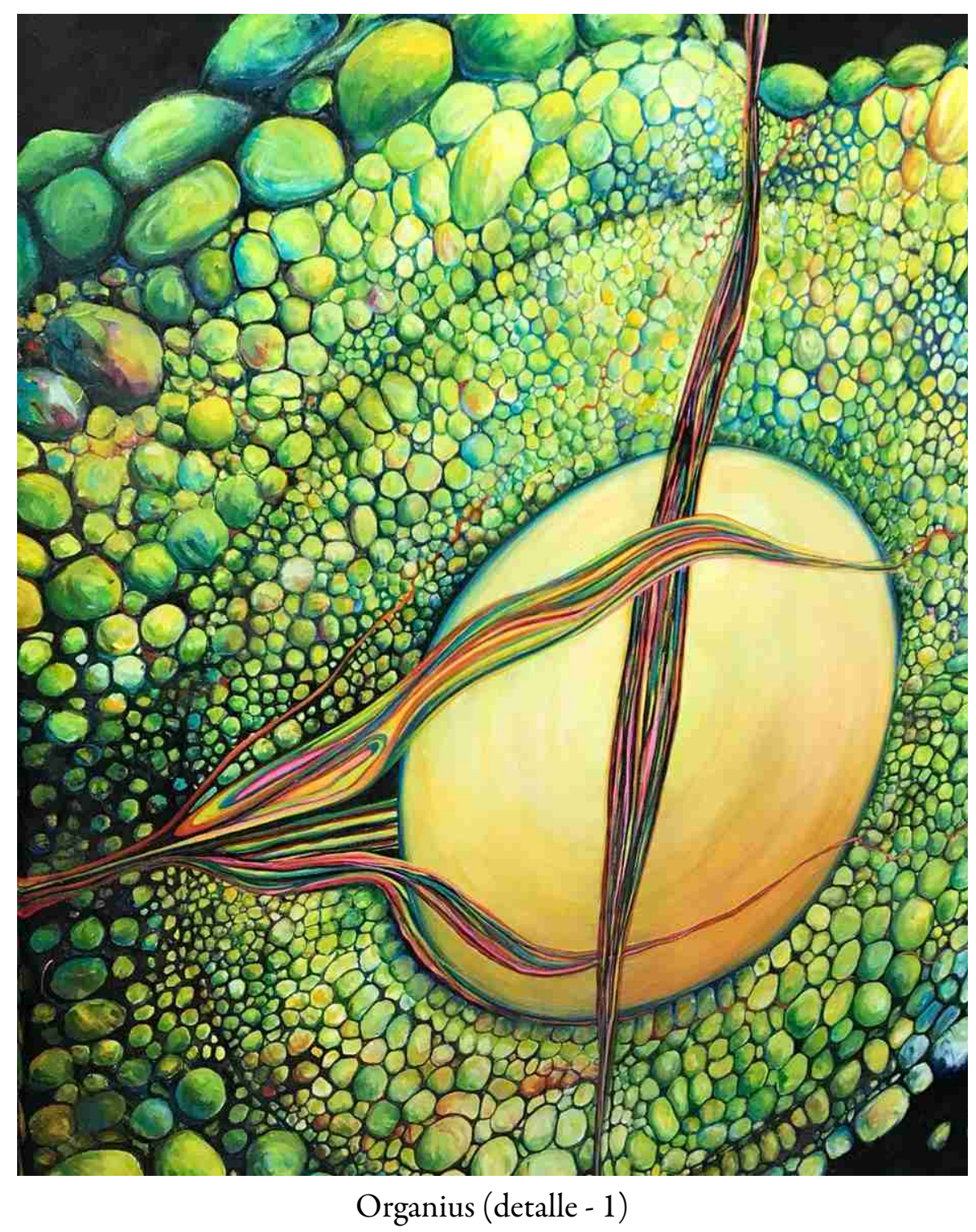




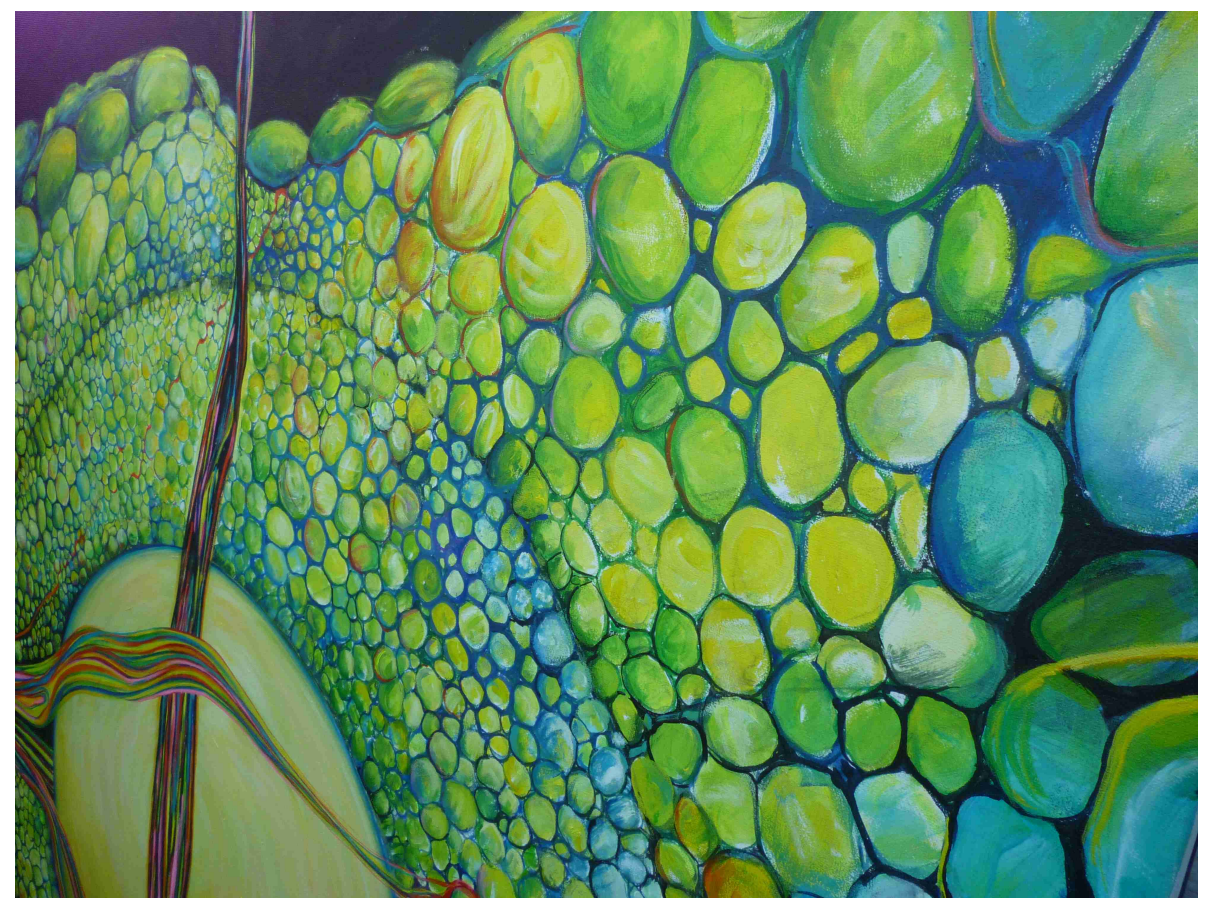

Organius (detalle - 2) 


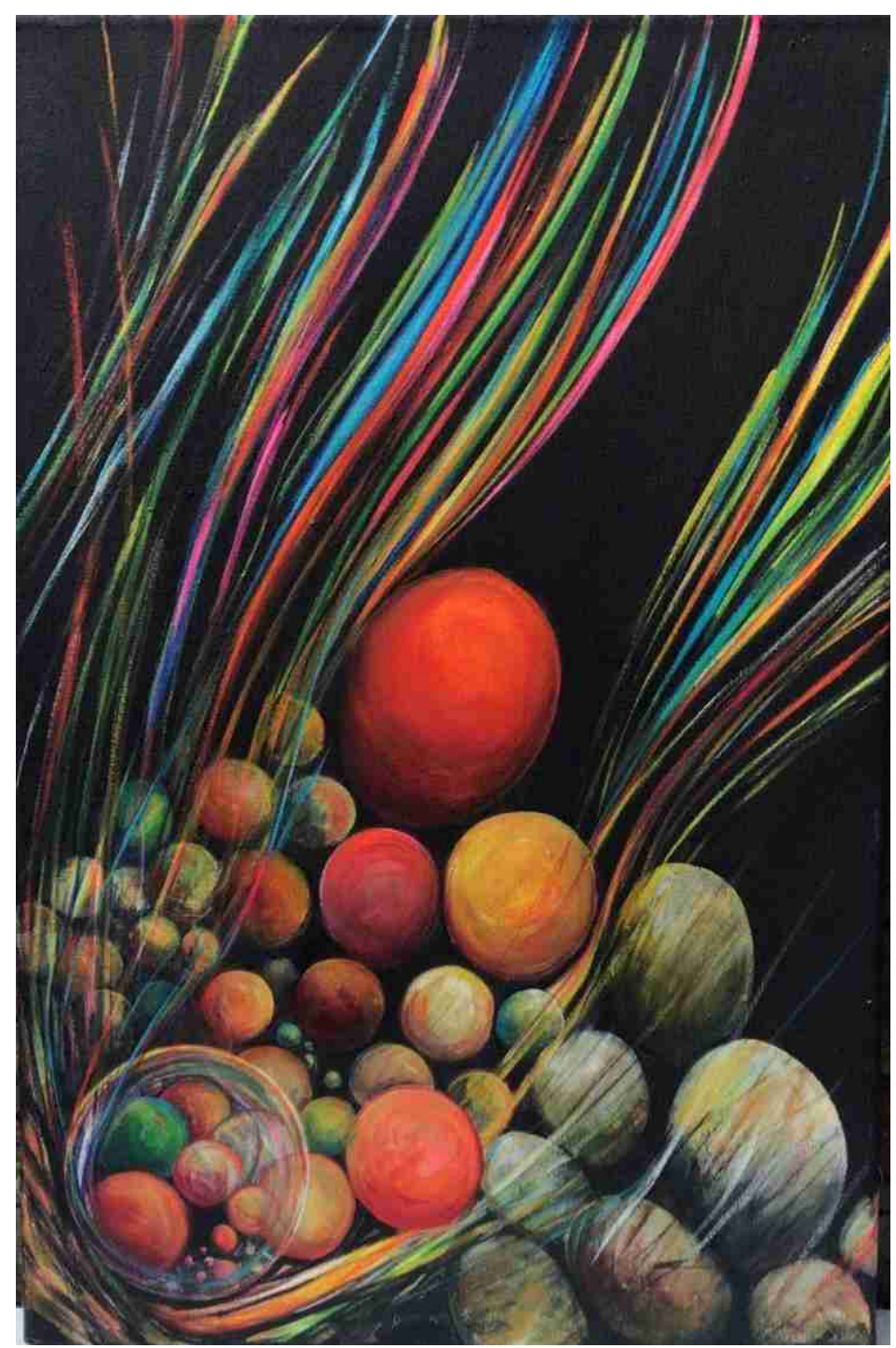

La Otredad I 


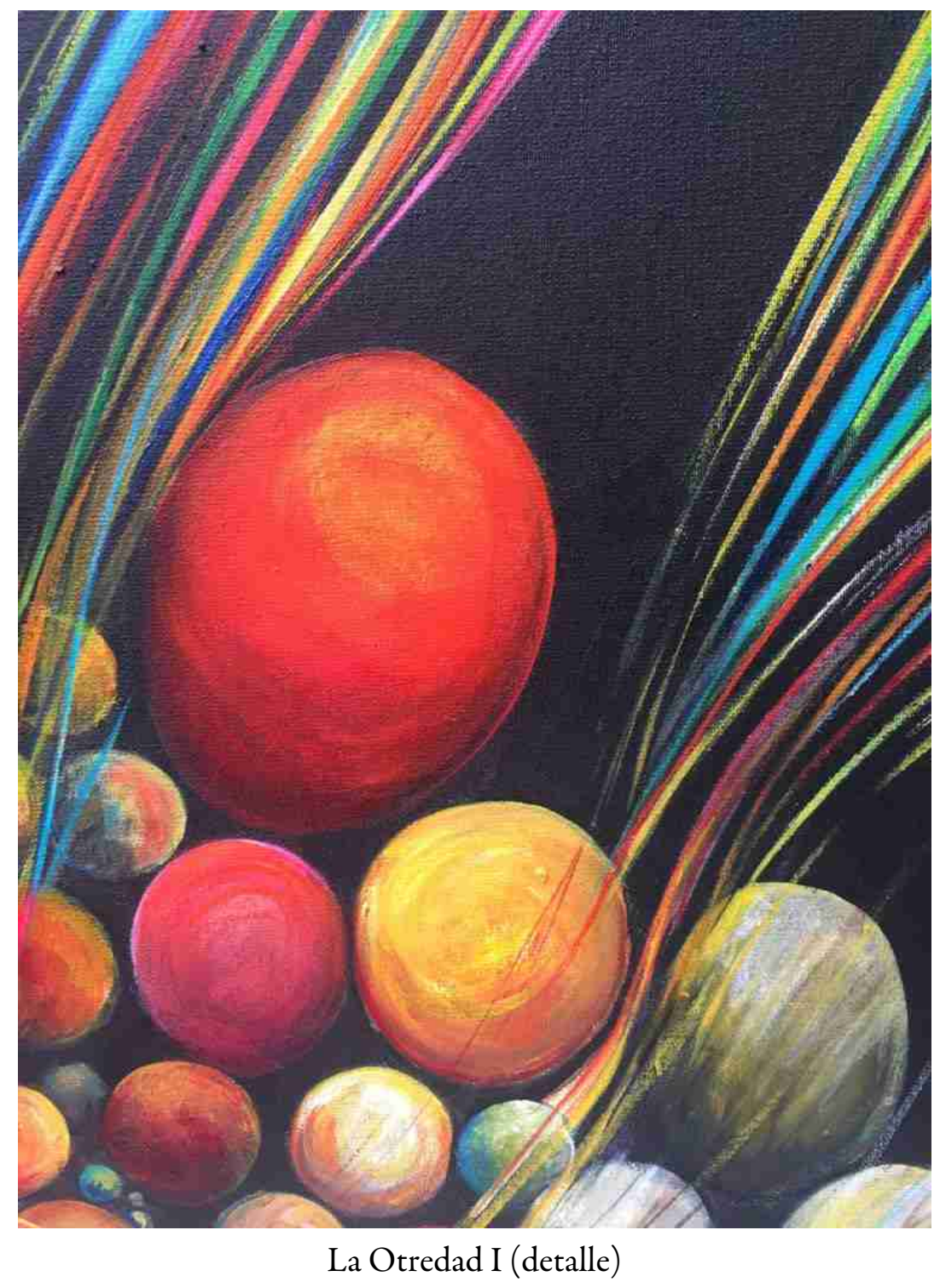




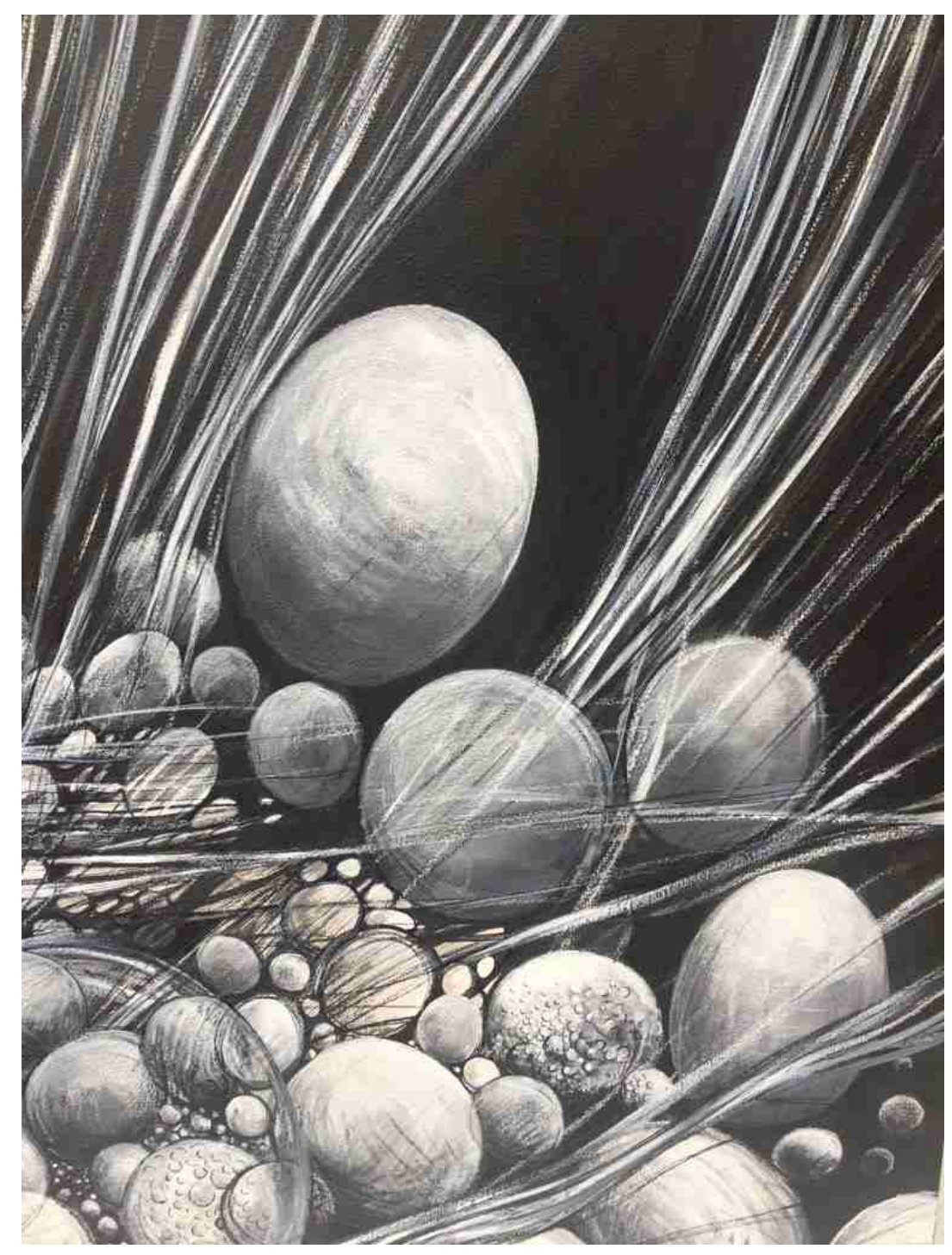

La Otredad II 


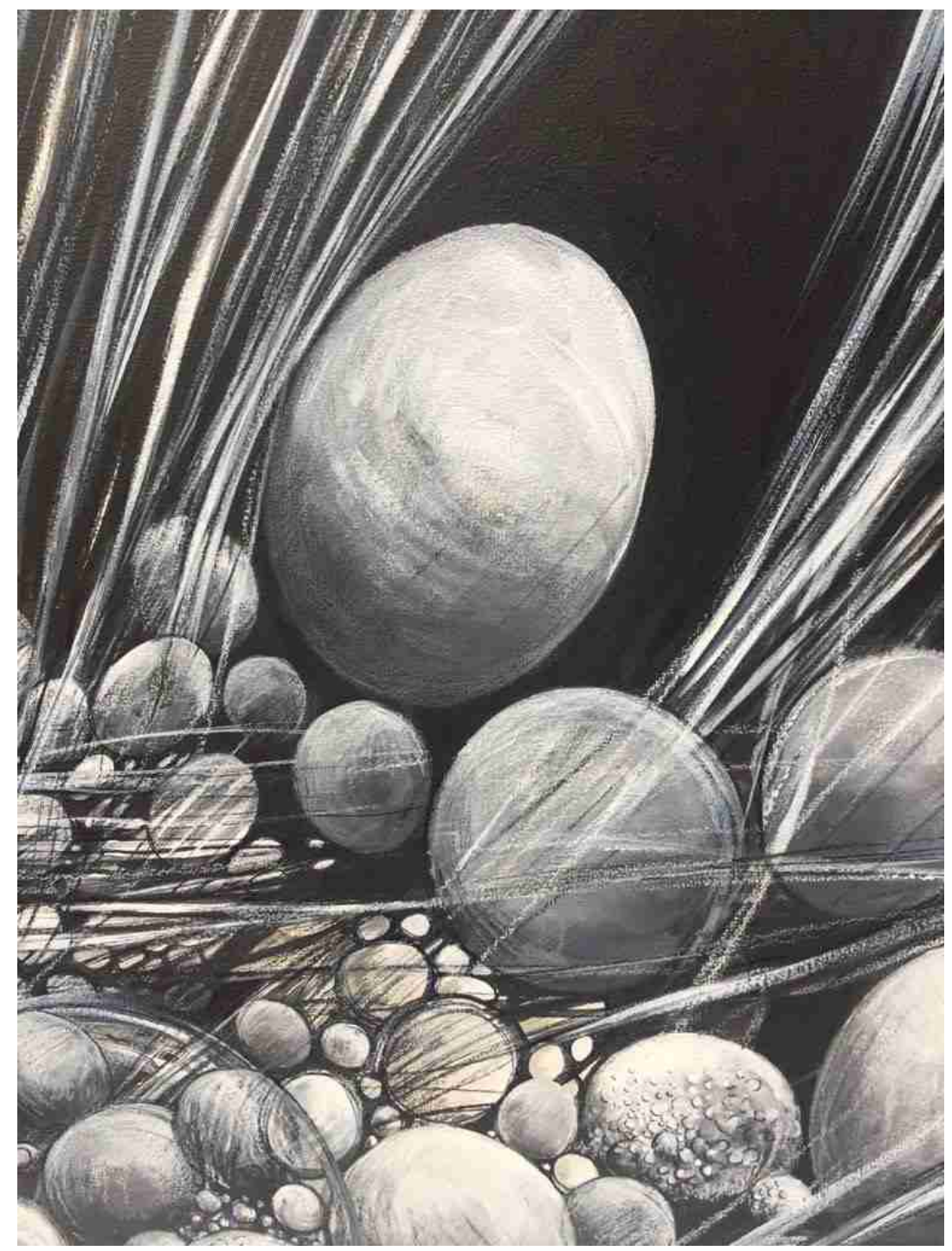

La Otredad II (detalle) 